Article

\title{
Entrepreneurial Ecosystems and Entrepreneurial Initiative: Building a Multi-Country Taxonomy
}

\author{
Mariana Pita ${ }^{1,2, *(\mathbb{D})}$, Joana Costa ${ }^{1,2,3}$ a and António Carrizo Moreira ${ }^{1,2,4}$ (D) \\ 1 DEGEIT-Department of Economics, Management, Industrial Engineering and Tourism, University of \\ Aveiro, 3810-193 Aveiro, Portugal; joanacosta@ua.pt (J.C.); amoreira@ua.pt (A.C.M.) \\ 2 GOVCOPP-Research Unit on Governance, Competitiveness and Public Policies, University of Aveiro, \\ 3810-193 Aveiro, Portugal \\ 3 INESC TEC - Institute for Systems and Computer Engineering, Technology and Science, Campus da \\ Faculdade de Engenharia da Universidade do Porto, Rua Dr. Roberto Frias, 4200-465 Porto, Portugal \\ 4 NECE-Research Unit in Business Sciences, University of Beira Interior, 6200-209 Covilhã, Portugal \\ * Correspondence: mariana.pita@ua.pt
}

Citation: Pita, M.; Costa, J.; Moreira, A.C. Entrepreneurial Ecosystems and Entrepreneurial Initiative: Building a Multi-Country Taxonomy. Sustainability 2021, 13, 4065. https:// doi.org/10.3390/su13074065

Academic Editors: João Leitão, Oliver Mauroner and Andrea Pérez

Received: 13 March 2021

Accepted: 3 April 2021

Published: 6 April 2021

Publisher's Note: MDPI stays neutra with regard to jurisdictional claims in published maps and institutional affiliations.

Copyright: (c) 2021 by the authors. Licensee MDPI, Basel, Switzerland. This article is an open access article distributed under the terms and conditions of the Creative Commons Attribution (CC BY) license (https:// creativecommons.org/licenses/by/ $4.0 /)$

\begin{abstract}
The main goal of this article is to appraise the existence of different patterns of the Entrepreneurial Ecosystems, to identify its relationship with Entrepreneurial Initiative, and recommend entrepreneurship policies that may influence the growth of entrepreneurial action. Without evidence on entrepreneurial ecosystems landscape and what determinants stimulate entrepreneurship in a given environment, policies could become flawed and miss the target. To address research purposes, the analysis was performed using data extracted from the Global Entrepreneurship Monitor (GEM) Database carried out between 2010 and 2016. To ensure a longitudinal perspective, it was used a balanced panel approach followed by Logistic Regression estimations. The article offers a novel and systematic approach, the Entrepreneurial Ecosystem Taxonomy, to overcome a disaggregated perspective on entrepreneurial ecosystems, between individual and context levels. Empirical findings capture four different country profiles, based on two measures: Entrepreneurial ecosystems and entrepreneurial initiative. The results allow to compare the four groups and appraise significant disparities around entrepreneurship determinants, namely, the education factor. While education is commonly recognized as a positive influence on entrepreneurship, the results suggest a contradictory effect. The existence of differentiated profiles and its determinants points outs the importance of developing specific entrepreneurship policy packages attending group specificities.
\end{abstract}

Keywords: entrepreneurial ecosystems; entrepreneurial initiative; entrepreneurial ecosystem taxonomy; Global Entrepreneurship Monitor

\section{Introduction}

The complexity of economic, societal and global challenges turned entrepreneurship into a powerful instrument to nurture business growth [1]. Its connection to innovation, job creation, and economic development made entrepreneurship a ubiquitous topic in the entrepreneurial policy literature [2]. During the last three decades, academics, practitioners, and policymakers encouraged by a fervent interest on discovering what influences entrepreneurship, presented mostly disarticulated approaches focused on the entrepreneur and on the entrepreneurial venture. More recently, the topic was redressed towards a more complex and systemic perspective resulting on the emergence of entrepreneurial ecosystems concept, where the entrepreneur and the entrepreneurial venture along with other contextual elements interrelate. The recognition of entrepreneurial ecosystems (EEs) as a community of multiple stakeholders concerned to create favorable environments to support new ventures [2] reinforced the importance of entrepreneurship policy [3]. In fact, during the last years, countries embedded entrepreneurship at the core of their public policies reflecting a strong commitment to foster broadly entrepreneurial spirit [4]. As a result, most 
of the countries have implemented entrepreneurship strategies and practical measures to ignite entrepreneurship and create conditions for entrepreneurs to act and strive.

The expansion of entrepreneurship support measures, the raise of entrepreneurship awareness, as well as the creation of strong entrepreneurial communities contributed to stimulate a global entrepreneurial climate [1]. Its progressive importance turned entrepreneurship a focal point of interest and raised the attention to a "new-fangled" and multidimensional paradigm revealing the need to observe the phenomenon through the lens of the individual, the company and the context [5].

The encouragement to implement supportive policies towards entrepreneurship in a global scale pushed economies to manage entrepreneurial ecosystems differently triggering the emergence of structural differences among underdeveloped, emergent, or developed countries [6]. As EEs gained preponderance, their space of action was expanded, leveraging an international perspective around the phenomenon revealing the importance of grasping the different realities $[7,8]$.

The formulation of several theories around entrepreneurial ecosystems contributed to the expansion of the literature focused on their elements and dynamics offering new, complementary, and even contradictory perspectives about EEs and their complexity. The results allowed to obtain theoretical contributions and empirical evidence about entrepreneurial ecosystems and entrepreneurial initiative, but its connection is still underdeveloped, along with its differences among countries [2,9]. Indeed, although entrepreneurial ecosystems could act as an enhancer of entrepreneurial activities [10], and entrepreneurs are more likely to engage in ecosystems with higher performance, the studies are still scarce exploring the entrepreneurship policy approaches in this milieu [11].

Recently, Content et al. [12] linked entrepreneurial ecosystems, entrepreneurial initiative, and economic growth within European regions and concluded that entrepreneurial ecosystems "matters and matters differently in different regions" unleashing the usage of new perspectives to explain the influence of entrepreneurship policies. On one hand, conventional metrics used to evaluate the entrepreneurship outputs, such as the number of new employments or businesses created, do not entirely apprehend the quality or performance of the ecosystem. On the other hand, if the objective is to foster the efficiency of EEs to tackle national challenges and grasp for efficient entrepreneurship policies, then it is important to explore their dimensions, considering territorial differences and their impact on business creation initiatives [13].

The global interdependence of other external factors as gross domestic product, unemployment or public debt impact world economies pushing the adoption of long-term public policies to overcome vulnerabilities and ensure economic renewal to face business downturns [14]. Instigated by competitiveness levels, entrepreneurial activity is superior in less developed economies and lower in extremely competitive economies [1]. More, in these environments, entrepreneurial spirit appears in capsulated structures, which recalls the need to assess the quality of EEs and entrepreneurship rates [1].

EEs follow an evolutionary perspective [11] and comprise several actors, and like any life cycle, if their actors do not contribute to their preservation, the EEs will decline. Therefore, the ecosystems should be sustainable and adaptable, permitting adjustments under the effect of turbulences [8]. Consequently, entrepreneurial ecosystems differ, evolve over time and influence entrepreneurial initiatives differently, depending on the individuals and their perception about the place where they are embedded. Moreover, given the specificities of each context, entrepreneurs face unique challenges and their willingness to enterprise is volatile.

To the best of our knowledge, no prior research attempts to explore the connection between entrepreneurial ecosystems and entrepreneurial initiative through a multidimensional and quantitative perspective [15] using an entrepreneurship policy approach, grounded on a taxonomic model. Inspired by the academic gap, this paper empirically tests a taxonomy aiming to provide an overview of EEs differences and similarities between countries [8,16] following context-specificities [17]. Additionally, the study seeks 
to provide quantitative evidence around EEs, allowing policymakers to fine-tune policy measures concerning entrepreneurship. The present work aims to address the following research questions: (1) "How does entrepreneurial ecosystems relate to entrepreneurial initiative?" and (2) "Does entrepreneurial ecosystems and entrepreneurial initiative differ from a country perspective?"

Considering this framework, particularly to entrepreneurship initiative, the main goal of the present article is to appraise the existence of different patterns of EEs, to identify the relationship with entrepreneurial initiative, and to identify entrepreneurship policies that may influence the growth of entrepreneurial action. Therefore, the final purpose of the study is to offer an integrative perspective about the EE phenomenon. Ultimately, the article seeks to contribute to grasp for more effective and adequate entrepreneurship policies according to individual and context singularities, improving entrepreneurship at large.

To address research questions, the present study splits into two main parts. Firstly, to expose the theoretical multidimensionality of the topic, is conducted a review on the most relevant contributions on entrepreneurial initiative and entrepreneurial ecosystems is conducted. Secondly, the empirical study analyses 21 economies relying on Global Entrepreneurship Monitor (GEM) database, within a timespan of 7 years.

Overall, this study makes three contributions. First, it takes a novel a systematic approach to tackle the relation between EE and EI, through the creation of a new comparative tool—Entrepreneurial Ecosystem Taxonomy (EET) — at country-level. Second, the comparison grounded on EET allows to establish four different profiles-Die-Hard, Go-Getter, Sugar-Coated, and Front-Runners-and to identify their divergent and similar EI determinants. At last, and following the results, an Entrepreneurship Policy Framework is presented with recommendations for policymakers with different directions to promote EI within contexts. By providing empirical evidence on within groups determinants of EI, the design entrepreneurship policies can be distinguished and become more effective.

After this introduction, the paper is structured as follows. Section 2 reviews the two main concepts-entrepreneurial ecosystems and entrepreneurial initiative and presents the theoretical framework. Section 3 exposes the methodology design regarding data collection and the analysis of the results following a quantitative perspective. Section 4 discusses the results and findings in light of previous studies. Section 5 presents the conclusions of the study, main limitations and future research perspectives.

\section{Entrepreneurial Ecosystems: A Review}

As entrepreneurship gained popularity, over the past two decades, academics and practitioners contributed with a plethora of studies on different topics, namely, venture financing, corporate entrepreneurship, social entrepreneurship and sustainability, entrepreneurial cognition, women and minority entrepreneurs, global entrepreneurial movement, family businesses, and entrepreneurial education [7]. The contributions proposed eclectic approaches, ranging from the individual, firm, region or country level.

Entrepreneurship has an interdisciplinary nature proved by the links with economics, managements, psychology, which may be extended to other academic fields. The recognition of entrepreneurship as a critical source of economic development and growth in most counties $[7,18]$ has increased the need of analyzing the underlining dynamics of new venture creation, since it depends on the interdependency of multiple context-based factors [19].

The concept of entrepreneurial ecosystems has captured the attention of researchers, practitioners and policymakers, during the last decade, leading to the explosion of this stream of research [17,19-24]. Consistently, different perspectives around the phenomenon were produced contributing to enlarge the scope of the topic, yet compromising the narrowness needed to understand its multidimensionality in depth [23].

While entrepreneurship dependency on the context is documented and its impact is marked by a bundle of different actors, the literature around EEs attempted to investigate and understand the ecosystems within respect to their constituents $[20,25,26]$ and 
the relation between these elements [24] throughout their life cycles [20]. Such studies allowed to capture a wide variety of EE configurations and highlighted their heterogeneous nature [27], evidencing the existence of nascent [25] and mature ecosystems [13] with diverse configurations.

More recent research on EEs tends to inspect the determinants of entrepreneurial activity using an exogenous approach, withdrawing the entrepreneur from the "picture" [26]. Entrepreneurs are individuals who recognize an opportunity and act, but they are not in isolation since they are dependent of certain elements to strive, as resources, infrastructures and support mechanisms [26].

Despite the insights gathered from the extensive research, the entrepreneurial ecosystem domain still remains conceptually fragmented [6] as the underlying mechanisms that influence entrepreneurs to take initiative and act are uncovered [26].

Prior studies demonstrate that entrepreneurial activity includes, simultaneously, "wannabe" entrepreneurs and, simultaneously, already established ventures, identifying different entrepreneurial types and phases of entrepreneurship [28]. It is important to unveil what countries are involved and to establish comparisons to underpin the determinants of entrepreneurial initiative in multiple settings. As entrepreneurial activity is the process by which individuals generate occasions for innovation [29] referring to early stage and established ventures, while entrepreneurial initiative encompasses the tentative of setting-up a business. As the environments affects the dynamics of entrepreneurial initiative, and being the entrepreneur embedded in a certain environment, the nexus between entrepreneurial ecosystems and entrepreneurial initiative cannot be disentangled from the entrepreneur and its individual characteristics [30]. This connection can provide effective insights about the discrepancies across countries and regions regarding entrepreneurship.

EEs are dynamic, local, social, institutional, and cultural processes that aim to nurture new venture creation and business growth [31]. This conceptual definition is aligned with the regional development literature, grounded on its geographical dimension to explain differences concerning social and economic performances, by appraising innovation or employment as outcomes [22]. At the same time, EEs are highlighted as the external environment of the business initiative where different combinations of processes or elements are set together, favoring entrepreneurial initiatives. Countries with fertile EEs and exhibiting high-quality entrepreneurship support services turn to be very attractive to entrepreneurs, broadening the outcome of the phenomenon, and facilitating entrepreneurs to develop their business with fewer obstacles [20].

The research contributions on entrepreneurial ecosystems continue to emerge but a deep understanding around how EE emerge, their change and how endogenous and exogenous factors influence them need to be appraised and compared among regions [24].

\subsection{Entrepreneur and Entrepreneurial Initiative}

Schumpeter considers entrepreneurs an innovators who challenge the status quo by exploiting opportunities that generate new organizational and technological innovations forcing others to react, instigating new business cycles and market change [28]. Therefore, entrepreneurship entails a process of discovery, evaluation and exploitation of new goods and services and the entrepreneur serve as the person who act to achieve those purposes [29].

It is acknowledged that some individuals behave more entrepreneurially than others, and to better understand such differences and uncover what ignites entrepreneurs to initiate a business, a large stream of research devoted their attention to explore entrepreneurs inner characteristics.

Commonly, analyzing entrepreneurial initiative entails the individual behavior and its ability to seize an opportunity, but not acknowledging the environment and its effect on the opportunity exploitation or individual desire to enterprise, narrows the phenomenon. 
According to Holcombe [30], knowledge and entrepreneurship are closely related considering that individuals may require specific knowledge, in a certain time and place, to seize entrepreneurial opportunities and act. The entrepreneur's endowment is expressed by education, skills and experience, and inspiration [31] influencing the opportunity recognition and ability to act [29]. Therefore, the entrepreneur is an "orchestrator" as she/he needs to combine multiple domains to access and mobilize the necessary resources to create a new venture.

Entrepreneurs take an active and self-starting approach [32] by spotting opportunities in the environment and use creativity, resilience, resourcefulness, vision, and optimism among others to bring innovation [31]. As a result, entrepreneurial initiative conducts individuals to achieve better results, a superior performance, be more innovative and entrepreneurial in general [33].

Analyzing entrepreneurial initiative only through exogenous factors has small explanatory power, as they usually influence directly intentions and behavior indirectly, through attitude changes as suggested by Ajzen and its Theory of Planned Behavior (TPB) The work of Ajzen [34] is of paramount importance as it explains the behavior of entrepreneurs and predicts entrepreneurial initiative. The TPB argues that entrepreneurial intention generally depends on perceptions of individuals' attractiveness, social norms and feasibility, conditioned by a situational dimension. A role-model can act as a "gamechanger" influencing the desirability to enterprise and enhance individual's awareness about an entrepreneurial career. The role-model may influence individual's self-efficacy, raising their perception of skills, knowledge and managerial competences which will increase the opportunity recognition. Therefore, to encourage entrepreneurial initiative and new venture creation, individuals and stakeholders perception about skills and opportunity to act must be positive [35]. Following this perspective, there are three relevant conditions that can be acknowledged as underpinning the entrepreneurial initiative, namely, the expected outcomes and desirability, the perceived social norms and self-efficacy (confidence). The availability of multiple theoretical and empirical works based on the TPB evidenced these factors as determinants of entrepreneurial behavior [36,37].

The Theory of Human Capital suggests that superior results are achieved in the context of entrepreneurship when background and experience are relevant on the business domain [31] appraising education in its different levels (primary, secondary, tertiary, formal, informal, vocational, or on-the job) as central contribution to economic growth [38]. Given the connection of this theory with the economics field, Sweetland [38] agrees that education has an economic component, that provides benefits to the individual and society. Moreover, cognitive factors related to knowledge and necessary skills to enterprise turn individuals more productive and efficient [36].

Entrepreneurship training and education exposes individuals to stories and cases of the discovery and exploitation of entrepreneurial opportunities, thus providing students with examples that they can relate to when encountering market gaps and undervalued resources [37]. Examples of successful entrepreneurs within the community provide a central focus for discussing the benefits and possibilities of entrepreneurship and demonstrate that it is a potential career path for students coming out of lower levels of education [18].

The entrepreneur has a central place in the $\mathrm{EE}$ and is the core actor in building and sustaining the ecosystem [39]. To date, several theories and models were applied to explain entrepreneurial initiative. However, to the best of our knowledge, the entrepreneurship research field lacks explanation about the relationship between individuals and their environment and the effect of this relationship on entrepreneurial initiative.

Emerging from the precedent debate, three aspects need further consideration: (1) Entrepreneurs are influenced by several factors, namely those related to individual characteristics; (2) entrepreneurs do not act in isolation and suffer influence from external driving forces; and (3) the entrepreneur is not only an outcome of the ecosystem but a key player contributing to its generation and maintenance, bi-directionally affected. Following the literature, Hypothesis 1 is formulated: 
Hypothesis 1. Raising education levels enhance entrepreneurial initiative.

\subsection{Entrepreneurial Ecosystems}

Entrepreneurial ecosystems represent an emergent area of research as the attention in the concept crosses different disciplines. The raise of the field as contributed to an evolving discussion with a significant number of studies produced in the past years. As the proliferation of studies about entrepreneurial ecosystems increased, the topic gained a less consolidated overview, presenting fragmented perspectives, which is reflected by a large number of current debates about its definition and scope. Entrepreneurial ecosystems are multi-actor and multi-scalar phenomenon which therefore entails personalized policy interventions [19].

\subsubsection{Concepts}

As an "underdeveloped" concept, diverse definitions of Entrepreneurial Ecosystems are presented in the literature. The entrepreneur is unquestionably a central actor in the entrepreneurial ecosystem and therefore the influence of other actors on the pathway of new venture creation must be determined [15]. The definition proposed by Stam [27] acknowledges "the entrepreneurial ecosystem as a set of interdependent actors and factors coordinated in such a way that they enable productive entrepreneurship", conducting individuals to act and add value to the society. On one hand, the entrepreneurial environment determines significantly whether and how entrepreneurship occurs, but on the other hand, the EE is also influenced by the entrepreneur behavior, in a reciprocal relationship [40]. The traditional perspective of entrepreneurial ecosystems implies the "interconnected set of entrepreneurial stakeholders in a regional entrepreneurial environment that fosters engagement in entrepreneurship to contribute to a prosperous regional economy" [40]. According to Brown and Mason [19] entrepreneurial ecosystems are linked to local economic development and promote new businesses as entrepreneurial actors, organizations, institutions and processes formally and informally mingle to connect, mediate, and control the performance within the local environment. Disregarding the interconnection of elements and tailoring entrepreneurship apart from own local circumstances can lead to perverse outcomes [41], particularly if lacks the presence of entrepreneurs.

\subsubsection{Agents}

The observation of failed entrepreneurship policies permitted to confirm that replication strategies to boost entrepreneurship is a trap as the coordination of a complex bundle of factors is connected to local conditions [42]. The selection of factors to turn places more attractive to enterprise and how the EE development is carried emphasizes the importance of a systemic overview of the concept. This is noted by De Brito and Leitão [43] since there is a preponderance on the constituents of the $\mathrm{EE}$ and its interaction among research results.

The entrepreneurial ecosystems concept soars from the seminal work untaken by Isenberg [44] and rapidly become an important reference to the field. Isenberg [44] believed that entrepreneurial ecosystems "represents a novel cost-effective strategy for stimulating economic prosperity" as a reaction to policy faults. The withdrawn of entrepreneurship as a policy priority, the lack of clear objectives towards entrepreneurship and the depreciation of entrepreneurship as a career option undertake the conditions to support selfsustained entrepreneurship. The proposed entrepreneurship ecosystem framework entails twelve elements combined in six domains-policy, finance, culture, supports, human capital, and markets-comprehending a complex interaction with "high bandwidth" nature.

While Isenberg [44] omitted causal paths in his framework, Stam [27] acknowledges EEs as a bundle of different factors and actors that interact organized to developed favorable environments towards entrepreneurship with entrepreneurial activity as the natural output. The author also presents the term productive entrepreneurship which encompasses a large understanding about entrepreneurial activity, including its total value, ranging from new 
businesses to failed enterprises. Therefore, the framework proposed distinguishes conditions, outputs, and outcomes, but disregards the entrepreneurial initiative as a separated action.

The literature acknowledges the importance of relational and institutional foundations to stimulate a dynamic interaction between multiple actors, institutions, and processes [3]. The authors propose a taxonomy with entrepreneurial actors, entrepreneurial resource providers, entrepreneurial connectors and entrepreneurial orientation. Within this concept, entrepreneurs and entrepreneurial infrastructures are central tenets to the system, with individuals influencing the local dynamics and emergence of EEs. Resource providers enable the transition of new ventures into potential growing firms, as diverse financial sources or accelerator programs. EEs typically consume a myriad of connections, based in formal and informal networks, which facilitate and complement new venture needs, contributing to raise a community perspective. The third stream of the taxonomy refers to culture and its impact as a key influence of the ecosystems. For instance, countries that have higher levels of entrepreneurship typically reflect an effective abundance of role-models, attracting more entrepreneurs.

Cao and Shi [2] review the EE literature and proposes a conceptual model for three entrepreneurial ecosystem dynamics based on resource (entrepreneurs and support resources), interaction (stakeholders' connection and network) and governance (policy tools) logic in emerging economies, as the phenomenon is mostly studied in developing economies. Using the level of economic development (indicated by GDP per capita), high growth potential (GDP growth rate) and stability of free market (market support institutions) the authors focused on 15 countries and used World Bank and GEM 2018 databases to understand how EEs works in such contexts. By providing a comprehensive framework of EEs dynamics and appraise factors that hampers the creation of new businesses-digital absence, resource scarcities, structural gaps and institutional voids-without neglecting that EEs are driven by individual opportunity interest.

Ecosystem management must be dedicated on whether the ecosystem as a full system, rather than pure economic and structural inducements, supports new venture creations and scale-ups [45]. As EEs comprise a multiplicity of different stakeholders or backup programs (regional/subnational/national governments, public sector bodies, and private organizations), more mature ecosystems might present a high level of institutional thickness reflecting an effective coordination between a sizable number of stakeholders with common objectives and vision of regional development [45].

According to [46] a region with high better economic performance may be better prepared to stimulate high growth ventures, but, at the same time, the presence of several innovation-driven companies will conduct to higher levels of competitiveness and prosperity. For instance, the case of Silicon Valley or Berlin presents a significant growth on entrepreneurial performance during the last years withdrawing the attention of other geographical pools of possible interest from less developed cases. As a consequence, many researchers attempted to determine how the community was generated and how it flourished along the years [47].

The growth of businesses reflects a stronger economy and in prosper environments job opportunities increase, diminishing the interest of individuals to enterprise, suggesting an undesirable relationship among economic development and entrepreneurial activity. In a contrary association, countries innovation-driven exhibit wider firm landscape dispersal with larger and smaller companies, industry and services, carrying a favorable prospect to the emergence of entrepreneurs.

Following the work of Porter [48], countries can be characterized according to their stage of economic development: Factor, efficient, and innovative-driven. Concerning entrepreneurship, while countries placed in factor driven stages display high rates of selfemployment, the efficiency-driven countries face a reduction of entrepreneurial activity as the economy becomes more competitive and stable [49].

This goes in line with various studies that have shown that outcomes and antecedents of entrepreneurship differ for different groups of countries according to level of develop- 
ment [50]. More, the success of EEs depends on the quality and quantity of interactions between internal and external stakeholders [51]. Hence, Hypotheses 2 and 3 are proposed:

Hypothesis 2. Better entrepreneurial ecosystems reinforce entrepreneurial initiative.

Hypothesis 3. Providing high quality entrepreneurial ecosystems along with higher education leverages entrepreneurial initiative.

\subsubsection{Stages}

On the work conducted by the World Economic Forum focused on understanding how entrepreneurship interrelates with economic competitiveness, what are the underlining conditions and how policymaking influences entrepreneurship, the results evidence that high entrepreneurial activity is exclusive to economies with low competitiveness [1]. Also, the study presents the preconditions to enterprise divided in four classifications: (1) Entrepreneurial connections; (2) awareness of opportunities; (3) inherent entrepreneurial skills; and (4) risk taking culture. The report also acknowledges in terms of policymaking, the type of entrepreneurial economy in which entrepreneurship policies are conducted, the desired entrepreneurial outcomes and the levers available to support the results. The promptness of individuals to conduit entrepreneurial efforts is not homogenous across geographic space and is affected by idiosyncratic preferences, regional characteristics and resources availability [52]. Thus, higher entrepreneurial capital, hence more knowledgeable individuals, within a region conduit to raise opportunity recognition and entrepreneurial ventures affecting positively economic growth. But an inverse relationship is also proven, with economic growth stimulating entrepreneurship. Audretsch and Keilbach [52] provide a heterogeneous picture about entrepreneurship phenomenon and its connection with economic growth, pointing that knowledge may not be satisfactory to guarantee competitiveness. With empirical evidence from Germany, the results point that investments in knowledge may have an inequitable impact on regions, suggesting that public policy must facilitate spill over and commercialization of knowledge through the encouragement of entrepreneurship.

The distinctive dynamics of entrepreneurship within countries underpinned several studies focusing emerging and developing economies, reflecting the inadequacy of a unidimensional perspective to understand a multidimensional phenomenon.

Marič et al. [53] unveil the difference between highly developed and emerging countries evidencing that countries with stronger and more developed economies have a negative effect on early-stage entrepreneurial activity and individuals tend to engage less in necessity-driven entrepreneurship. In contrary, countries that are growing faster, exhibit low unemployment rates and individuals tend to pursue opportunity driven entrepreneurship.

Roundy [9] introduces the differences between emerging and developed places indicating striking disparities between their resources, as less support organizations, network, pool of talent or role-models occur. Such differences suggest that specific policy approaches must follow the variation and size of entrepreneurial ecosystems. According to Cao and Shi [2], the emerging economies exhibit similarities including digital absence, resources scarcities, structural gaps, and institutional holes. The shortage of digitalization could notably coerce the prosperity of entrepreneurial ecosystems as impacts transversally business creation. Regarding insufficient resources, emerging economies should leverage international knowledge connections to stimulate the contact and knowledge capture. As the government support programs are limited, new businesses do not have conditions to attract high-quality personnel, evidencing resources inadequacy.

As the assortment of entrepreneurship and environment become important, the evolutionary stages of entrepreneurial ecosystems in both developed and emerging countries lacks explanation [6]. Indeed, the diversity of contexts should be investigated by pondering alternative elements of the ecosystems, along with a time and space reflexion. 


\subsection{Taxonomy}

The multidimensional complexity of entrepreneurial ecosystems and its place-sensitiveness supports the analysis of the phenomenon through the lens of nations.

Studies tend to rely on countries that exhibit mature or emerging economies [11], leaving behind "places that don't matter" [54]. The entrepreneurial process and the evolution of ecosystems results from dynamic changes along time, as entrepreneurial ecosystems cannot be instantly built encompassing years of constant efforts [20]. Each ecosystem (or potential ecosystem) should be considered as unique, with distinctive characteristics requiring location-specific programs and support [11]. For the authors, "peripheral places" regularly struggle with the lack of social, cultural and critical thinking and economic resources, making those EE lag behind when compared to more advanced environments.

Although the progression of the studies, entrepreneurship policymaking tends to be complex since entrepreneurial action depends on individual motives and the context in which they are embedded. Without evidence on entrepreneurial ecosystems landscape and what determinants stimulate entrepreneurship in a given environment, policies could become flawed and miss the target.

Considering the prior mentioned research, the present study extracts two main dimensions related to entrepreneurial ecosystem phenomenon, specifically, entrepreneurial ecosystem quality and entrepreneurial initiative. This approach emphasizes the relationship between entrepreneurial ecosystems quality using a country-based perspective and its connection with entrepreneurial initiative of individuals $[2,9,53]$ and uses the performance average as a threshold to assess its positioning.

The taxonomy represented in Figure 1 offers a model that encompasses two variablescountry Entrepreneurial Ecosystem Quality (EEQ) and individual Entrepreneurial Initiative (EI). The Entrepreneurial Ecosystem Taxonomy (EET) is a classification system that provides four typologies of different EEs deployed under two main sources of empirical evidence (EEQ and EI). The classification breaks the world of EEs into categories, ordering, comparing, and clustering countries without losing sight of the latent richness and diversity that exists within the type [55]. This system acknowledges that EEs are either all similar or are all individually inimitable, asserting the multidimensional nature of each typology. In this perspective, the taxonomy offers an ordered scheme, grounded on the recognition of specific similarities, consistent with previous theoretical and practical studies. Following the recommendations of Rich [55] the EEs taxonomy provides four major divisions, within the first group (Die-Hard type) and the last group (Front-Runners type) representing the lowest and the highest category levels. The specific typologies of EET are Die-Hard, Go-Getter, Sugar-Coated, and Front-Runners. Die-Hard type is considered the inferior position within EET framework and refers to countries with lower levels of EEQ and EI. The usage of Die-Hard evidence the inexorable lack of conditions and efforts to enterprise. The second position, Go-Getter, captures more ambitious individuals expressing higher EI. These economies reveal a shortage of EEs conditions and, consequently, a poorer EEQ. The third type is named Sugar-Coated and addresses countries with attractive EEs. This taxonomic position evidence limited EI opposing to outstanding context conditions. At last, Front-Runner's type represents the leading economies in both dimensions, evidencing higher levels of EEQ and EI.

In sum, the EET model highlights the diversity of EEQ and EI, deploying a classification system capable of characterizing economies according to four different positions. 


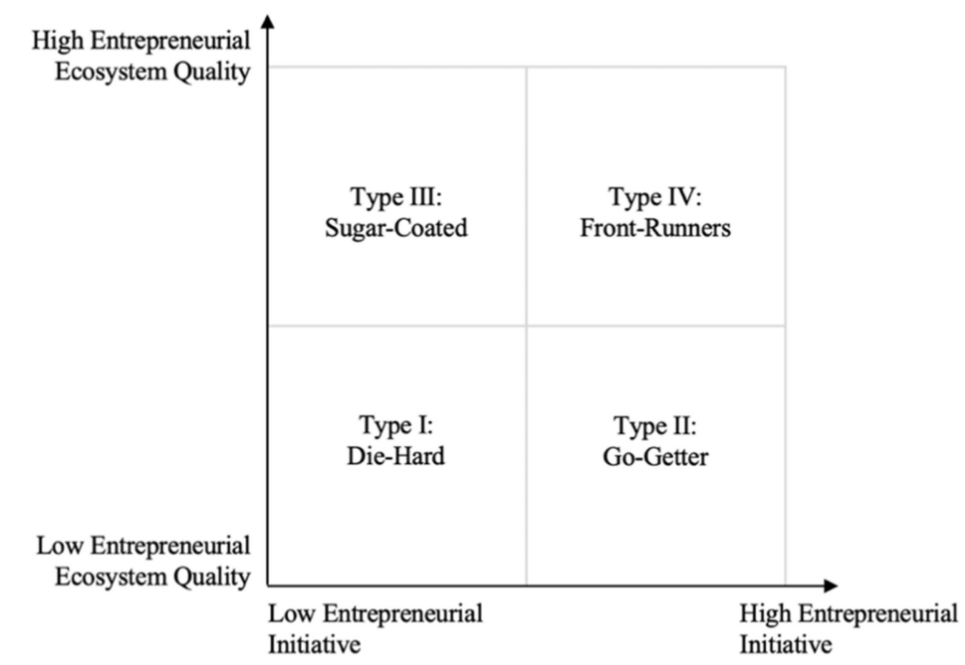

Figure 1. Entrepreneurial Ecosystem Taxonomy.

\section{Methodology}

The methodology employed was based on the development of a balanced panel with multiple countries, followed by a logistic regression to link entrepreneurial initiative and entrepreneurial ecosystems.

\subsection{Database}

The analysis was performed using data extracted from the Global Entrepreneurship Monitor (GEM) Database carried out between 2010 and 2016. GEM represents the large survey-based research on entrepreneurship and entrepreneurial ecosystems around the world on an annual basis (methodological details concerning the data collection can be found in https:/ / www.gemconsortium.org/wiki/1599, accessed 1 April 2020). The work developed by Reynolds et al. [56] and Levie and Autio [57] were seminal contributions to GEM framework and allowed to tackle different dimensions of the multi-faceted EE phenomenon and measure EI. As reported by several authors [12,56,58,59] GEM offers a solid theoretical framework allowing to capture heterogenic, large, reliable, and comparable data about entrepreneurship environment and activity, worldwide. For the purpose of the study, the data extracted corresponds to 7 years, covering a recent economic cycle (available data details can be found in https:/ / www.gemconsortium.org/data, accessed 1 April 2020). The inclusion of a large number of countries within the balanced panel, limited the period of the study, thereby, excluding the last available dataset (2017).

GEM framework is based on two levels of analysis [24]: Micro-based on individuals, and macro-extracted from experts to report the ecosystem's support conditions. Concerning micro-level purposes, the model captures Entrepreneurial Initiative (EI) and provides significant associations between entrepreneurship and individuals' attitudes, beliefs, and characteristics. On a macro-level, the Entrepreneurial Framework Conditions (EFCs) proposed by Levie and Autio [37] intends to mirror the EE as the exogenous environment and understand the effect of context on new venture creation, through nine conditions: Finance, Government Policies, Governmental Programs, Education and Training, R\&D Transfer, Commercial and Service Infrastructures, Market Openness, Physical Infrastructures, and Cultural and Social Norms. GEM admits a positive effect of the EE on EI [37] but its impact on EI along EE quality using a country-group perspective are still uncovered, to the best of our knowledge.

\subsection{Variables}

The variables used (dependent, predictors and controls) were extracted from the GEM APS 2016 and are described in Table 1. Additionally, a variable to capture the overall 
economic context was included, through the Gross Domestic Product (GDP) per capita of each country, to appraise purchasing power parity, collected from the World Bank database (available data details can be found in https:/ / data.worldbank.org/indicator/NY.GDP. MKTP.CD, accessed 1 May 2020).

Table 1. Variable description.

\begin{tabular}{|c|c|c|}
\hline Variable & Description & Type \\
\hline Entrepreneurial Initiative (EI) & $\begin{array}{l}1=\text { individuals currently trying to set up a business. } \\
0=\text { otherwise }\end{array}$ & Binary \\
\hline Gender (GEN) & $1=$ female individuals. $0=$ otherwise & Binary \\
\hline Age (AGE) & $\begin{array}{l}\mathrm{L} 1=\text { under } 18 \text { years; } \mathrm{L} 2=18-24 \text { years; } \mathrm{L} 3=25-34 \text { years; } \mathrm{L} 4=35-44 \text { years; } \\
\mathrm{L} 5=45-54 \text { years; } \mathrm{L} 6=55-64 \text { years; } \mathrm{L} 7=\text { more than } 65 \text { years. }\end{array}$ & Multinomial \\
\hline Education (EDU) & $\begin{array}{l}\mathrm{L} 0=\text { no education; } \mathrm{L} 1=\text { pre-primary education; } \mathrm{L} 2=\text { primary } \\
\mathrm{L} 3=\text { secondary } ; \mathrm{L} 4=\text { practical courses } \text { L5 = degree; } \mathrm{L} 6=\text { master or upper. }\end{array}$ & Multinomial \\
\hline Social Context (SOC) & $\begin{array}{l}1=\text { individuals that personally know someone who started a business. } \\
0=\text { otherwise. }\end{array}$ & Binary \\
\hline Opportunity Recognition (POR) & $\begin{array}{l}1=\text { individuals that recognize future business opportunities. } \\
0=\text { otherwise. }\end{array}$ & Binary \\
\hline Skills Perception (SKP) & $\begin{array}{l}1=\text { individuals that perceive having the skills and knowledge to } \\
\text { enterprise. } 0=\text { otherwise. }\end{array}$ & Binary \\
\hline Fear to Fail (FTF) & $1=$ individuals that fears failure. $0=$ otherwise & Binary \\
\hline Social Regulation (SOR) & $1=$ individuals that prefer similar standards of living. $0=$ otherwise. & Binary \\
\hline Entrepreneurial Desirability (END) & $\begin{array}{l}1=\text { individuals that consider entrepreneurship a desirable career choice. } \\
0=\text { otherwise. }\end{array}$ & Binary \\
\hline Entrepreneurship Status (ENS) & $\begin{array}{l}1=\text { individuals that consider entrepreneurship as having a high level of } \\
\text { status. } 0=\text { otherwise. }\end{array}$ & Binary \\
\hline Entrepreneurship Exposure (EEX) & $\begin{array}{l}1=\text { individuals exposed to entrepreneurship stories in public media. } \\
0=\text { otherwise. }\end{array}$ & Binary \\
\hline Entrepreneurship Easiness (EEA) & $1=$ individuals that considers easy to start a business; $0=$ otherwise. & Binary \\
\hline Social-Driven Entrepreneurship (ESD) & $1=$ individuals' recognition of social entrepreneurship. $0=$ otherwise & Binary \\
\hline Country Stage of Development (CAT) & $\begin{array}{l}\text { CAT1 }=\text { factor driven economy } ; \text { CAT2 = efficiency-driven economies; } \\
\text { CAT3 = innovation-driven economies. }\end{array}$ & Multinomial \\
\hline Gross Domestic Product (GDP) & Country Gross Domestic Product per capita & Continuous \\
\hline
\end{tabular}

\subsection{Research Methods}

The empirical study was conducted in two phases, within different steps, to address the two research questions defined in the introduction. Other studies grounded on GEM adopted the same method [59] due to the binary nature of the dependent variable, ensuring the appropriateness of methodological options. The effect of EI determinants was estimated using models of logistic regression, contributing to consolidate the empirical research landscape with a new taxonomic approach.

Phase one: Firstly, in order to develop a comprehensive overview about the empirical patterns of the entrepreneurial ecosystem quality, a three-stage exploration process was applied.

Step one: The data used was collected from the GEM Adult Population Survey (GEM APS) and the GEM National Expert Survey (GEM NES), between the years 2010 and 2016, using the last public available dataset. Since databases differ in scope (on a micro and macro level), the dataset was harmonized to guarantee the feasibility and reliability of balanced panel approach. This methodological option ensured the time and space overview, following a balanced panel, dropping out cases without representation during the overall 
7 years. This procedure allowed to extract data from 21 countries: Spain (ES), Greece (GR), Slovenia (SI), Hungary (HU), South Africa (ZA), United Kingdom (GB), Argentina (AR), Brazil (BR), Uruguay (UY), Croatia (HR), Peru (PE), Colombia (CO), Switzerland (CH), Finland (FI), Germany (DE), Malaysia (MY), Portugal (PT), Sweden (SE), Mexico (MX), Ireland (GBI), and Chile (CL). All data was compiled according to the GEM protocol.

Step two: To obtain EI per country and per year, statistical procedures were implemented after data harmonization. Afterward, using similar techniques, the average of EE was determined per variable, per year and per country. Considering that all of the dimensions of an EE contribute equally to its quality, a new indicator was conceptualized-the Entrepreneurial Ecosystem Quality (EEQ). After obtaining the EEQ and EI, it was possible to evaluate the progress of EE in a diachronic and geographic perspective [60]. The analysis described similarities and differences between countries, and the connection between the EEQ and EI was further debated over time.

Step three: Considering the prior results, a new taxonomic scheme-Entrepreneurial Ecosystems Taxonomy (EET) - was explored to capture the overall position of the countries, concerning their EEQ and EI, in the years 2010 and 2016. Despite the fact that there is information on all of the years between 2010 and 2016, the years between those two exact years were left out on purpose in order to identify eventual structural breaks since the impact of structural changes is not traceable in the short-term, which justifies the midseries lag.

Phase two: After the implementation of the EET, and using the taxonomic quadrants for cross-section purposes, the relation between the EEQ and EI was examined through binary logistic regression analysis. Econometric estimations were run based on sub-sampling segmentation which was based on the groups placed in each quadrant. The same model was applied to all, considering microeconomic data from the GEM APS 2016 (since it is the last one that is openly obtainable), in order to address if the determinants of the EI apply to each taxonomic category.

\section{Results}

\subsection{Phase One: Entrepreneurial Ecosystems Taxonomy}

The analysis of the Entrepreneurial Ecosystems Taxonomy (EET), shown in Figure 2, allows us to evaluate the dynamics concerning the entrepreneurship ecosystem quality (EEQ) and entrepreneurial Initiative (EI) of each country-and observe the evolution in two different moments: 2010 (shown in orange) and 2016 (shown in green).

As captured, there are some changes throughout the years, with some countries dropping their position or conquering a new one, while others remain in the same quadrant despite the time gap between those two moments.

The EI was measured as a binary variable ( 0 and 1$)$, and in 2010 the mean value reported was 0.087. The countries that exhibit a better performance both in the EEQ and in EI, and therefore, are considered as "front-runners" are, surprisingly, Colombia, Mexico, and Uruguay. Among those three countries, Mexico is the strongest with a better positioning in both dimensions. The results were unexpected, since these countries are not usually considered as innovative, and they do not display stronger economies. Also, there is an absence of European countries in the quadrant, which can lead us to believe that there are territorial singularities, deserving further analysis.

In contrast, the countries poorly ranked in both dimensions, positioned in the "diehard" group in 2010 are: Greece, Hungary, Spain, Portugal, Sweden, Slovenia, and Croatia. The results revealed the lack of entrepreneurial initiative and entrepreneurial conditions since they were all placed below the average. It is interesting to acknowledge that this cluster only encompasses European countries, which suggests a geographical dimension of the phenomenon. 


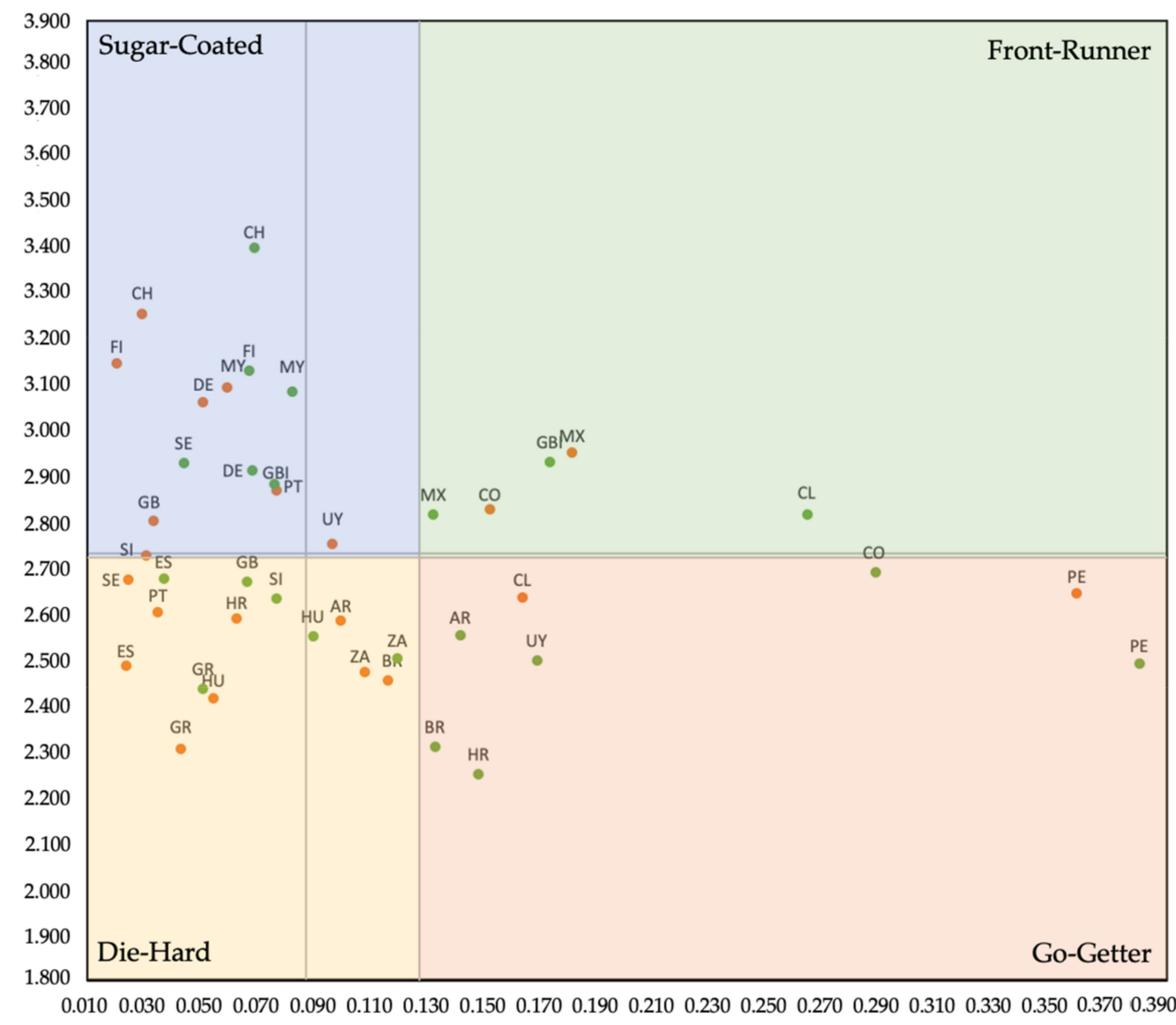

Figure 2. Entrepreneurial Ecosystem Taxonomy (2010-2016).

The findings also reveal six countries classified as "sugar-coated", meaning that all of these countries had a higher performance concerning EEQ, and a lower rank regarding entrepreneurial initiative (Finland, United Kingdom, Ireland, Germany, Switzerland, and Malaysia). It is surprising to find countries from two different regions in this clusterEurope and Asia-since they tend to follow distinctive innovation and entrepreneurship. Switzerland is the most prominent country when it comes to EEQ, nevertheless, it is one of the countries with the lowest level of entrepreneurial initiative. Ireland, in contrary, performs more positively in terms of EI, but it also reveals less favorable conditions of the EEQ compared to Germany or the United Kingdom.

The "go-getter" quadrant includes countries with higher levels of EI, but lower levels of EEQ. In this quadrant, one may find Argentina, South Africa, Brazil, Chile, and Peru. Surprisingly, the cluster only gathers non-European countries, with representatives of Latin America and Africa. As extensively recognized, these countries historically display unstable economies and tend to have unequal societies. Nevertheless, they still have higher entrepreneurial dynamism when compared to European countries.

The analysis performed, concerning 2010, gave us a clear understanding of the dissimilarities in the EEQ and EI between countries and it also allowed the establishment of a new categorization of entrepreneurial ecosystems. As expected, more developed countries possess better conditions to enterprise. But surprisingly, despite having the necessary encouragement to enterprise, in terms of infrastructures, funding support, governmental programs, market openness or education, which is the case of Finland or Sweden, the entrepreneurial Initiative is very scarce, particularly when compared to countries like Argentina or South Africa. Such difference could be justified by the inequalities in terms of job market opportunities and income, instigating necessity-driven entrepreneurship. 
As more developed economies tend to provide better job opportunities and stable revenues, the number of those who decide to enterprise are low.

The year of 2016 reports significant differences when compared to 2010, particularly among the countries which are better ranked concerning entrepreneurial initiative and the Entrepreneurship Ecosystem Quality. From 2010 to 2016, the progress of EI was positive, moving from 0.087 to 0.127 ; in contrast, EEQ decreased from 2.735 to 2.723 .

The group labelled as "front-runners" in 2016 is composed by three countries: Mexico, Ireland and Chile. However, only Mexico maintains its position when compared to 2010, with Colombia leaving the group. Unexpectedly, the new entries come from different quadrants: Ireland came from the "sugar-coated" group and Chile left its position as a "go-getter".

Mexico presents a similar pattern, although it still maintains its position as a "frontrunner". On the other hand, Ireland joins the front-runners and achieves the second-best position regarding EI. Surprisingly, the EEQ did not increase in the same proportion, but it seemed to be enough to trigger entrepreneurial behavior. Chile exhibits an analogous performance, going from the "go-getters" group to the most advantageous position within the "front-runner" quadrant concerning EI.

On the contrary, the "die-hard" group presents two new entries, namely, United Kingdom and South Africa. Although the country faced a decrease of the EEQ, EI reached twice the value of 2010. Spain, Greece, Hungary, and Slovenia maintained their position within the group, with positive movements in both dimensions, although its performance remains below the average. The results suggest a positive relationship between the promotion of EEQ and EI. It should also be noted that three countries moved to other quadrants, namely Sweden, Portugal and Hungary, when compared to 2010. As for the first and second country, the results demonstrate a significant increase in terms of the EEQ which allowed them to enter on the "sugar-coated". The other remaining country (Croatia) moved to the "go-getter" quadrant, revealing a noteworthy increase of EI. For instance, EI in Hungary nearly doubled when comparing to 2010. The remaining countries progressed more slowly.

"Sugar coated" stands in 2016, with four countries maintaining their position since 2010 and two new entries. Switzerland, Finland, Germany, and Malaysia reveal positive signs of progress in terms of EI. Nevertheless, only Switzerland raised its EEQ. On the contrary, Germany faced a decrease regarding EEQ while Finland and Malaysia maintained their EEQ levels. However, this did not affect their EI performance. The results also posit Sweden and Portugal in this quadrant. It should be mentioned that both of these countries were in the "die-hard" group, which reveals a significant increase in their EEQ. In regard to Portugal, the impact in its EI was twofold when compared to 2010.

The results underpin the "go-getter" group and reveal three new entries: Uruguay, Croatia and Colombia. Uruguay and Colombia leaved the "front-runners" group due to a decrease in EEQ contributing to a downturn in entrepreneurship. Croatia came from the "die-hard" group, enlightening the growth of EI, although the EEQ declined in some cases.

Argentina, Brazil, and Peru maintain its position within the group, evidencing a cutback in its EEQ. However, its increase in EI shows an outstanding performance of the country in terms of new venture creation.

The analysis based on the EET reveals an outstanding performance of Latin-American countries regarding EI, as proved by Peru's, Colombia's and Chile's position. With an opposite behavior, in general, European countries disclose a weak performance regarding EI. With the purpose of determining the EE taxonomic dynamism among the countries, Table 2 reveals the changes between quadrants, if any, and determines the type of movement (ascending or descending) according to the countries taxonomic position. As observed, twelve countries do not undergo changes concerning taxonomic position. Also, it is clear that there is not a quadrant effect since it is transversal. In addition, it seems that there is no influence regarding GDP, because countries that have faced increase and decrease posit in the same spot. Only two countries-Portugal and Sweden-faced an increase in EEQ and EI, with Portugal taking a huge leap forward. Once again, this positive increase in Sweden is the opposite of their GDP performance. Out of the five countries that faced 
a decrease in their position, Colombia and Uruguay performs the most evident change since both faced a decrease of two positions. Nevertheless, there is only one country (Peru) with higher EI which exposes the country's entrepreneurial spirit. Surprisingly, the GDP in Colombia increases strongly between the years 2010 and 2016.

Table 2. Entrepreneurial Ecosystems Taxonomic Dynamics.

\begin{tabular}{|c|c|c|c|c|}
\hline Country & GDP * 2010 & GDP * 2016 & Taxonomic Dynamic & EET 2016 \\
\hline Spain & -0.297 & 2.944 & $=$ & Q1 \\
\hline Greece & -5.601 & 0.225 & $=$ & Q1 \\
\hline Slovenia & 0.903 & 3.046 & $=$ & $\widehat{\mathrm{Q}} 1$ \\
\hline Hungary & 0.892 & 2.502 & $=$ & Q1 \\
\hline Portugal & 1.691 & 2.342 & $\Uparrow$ & $\widehat{\mathrm{Q} 3}$ \\
\hline Croatia & -1.273 & 4.209 & $\Downarrow$ & Q2 \\
\hline Sweden & 5.288 & 1.134 & $\Uparrow$ & Q3 \\
\hline Argentina & 9.300 & -3.110 & $=$ & Q2 \\
\hline Brazil & 6.524 & -4.069 & $=$ & $\widehat{\mathrm{Q}} 2$ \\
\hline Uruguay & 7.495 & 1.330 & $\Downarrow$ & Q2 \\
\hline Chile & 4.750 & 4.209 & $\Uparrow$ & $\widehat{\mathrm{Q}} 4$ \\
\hline Peru & 7.455 & 2.423 & $=$ & Q2 \\
\hline South Africa & -1.061 & 1.551 & $\Downarrow$ & Q1 \\
\hline Switzerland & 1.936 & 0.618 & $=$ & $\widehat{\mathrm{Q} 3}$ \\
\hline Finland & 2.715 & 2.333 & $=$ & Q3 \\
\hline Germany & 4.339 & 1.408 & $=$ & $\widehat{\mathrm{Q} 3}$ \\
\hline Malaysia & 5.624 & 3.041 & $=$ & Q3 \\
\hline U. Kingdom & 1.153 & 1.149 & $\Downarrow$ & Q1 \\
\hline Ireland & 1.257 & 2.514 & $\Uparrow$ & Q4 \\
\hline Mexico & 3.617 & 1.680 & $=$ & Q4 \\
\hline Colombia & 0.708 & 3.257 & $\Downarrow$ & Q2 \\
\hline
\end{tabular}

\subsection{Phase Two: Entrepreneurial Ecosystems Taxonomy and EA Determinants}

The descriptive statistics shown in Table 3 provide summaries about the variables used. The sample of the Die-Hard quadrant (Q1) is composed of a total of 41,018 individuals. Almost $95 \%$ are not engaged in entrepreneurial efforts. The sample which represents the GoGetter quadrant (Q2) is composed of 12,127 individuals and shows a higher performance of EI when compared to the first group, reaching a total of $21.11 \%$. As for the Sugar-Coated quadrant (Q3), the sample comprises 18,618 individuals and only $6.41 \%$ are engaged in entrepreneurship. At last, the Front-Runners group (Q4) includes 16,264 individuals and more than $20 \%$ are enterprising. In regard to "education", the three groups-Die-Hard, GoGetter and Sugar-Coated-reveal similar levels of instruction. Almost 25\% of the sample has a higher education. However, the Sugar-Coated quadrant shows that individuals have upper levels of education. The data evidence the prevalence of secondary level of education among the groups. In regard to "social context", individuals from Q4 have more personal contact and interaction with entrepreneurs (41.27\%). Surprisingly, the same group does not reveal similar performance in terms of media influence. Both groups, GoGetter (59.14\%) and Sugar-Coated (61.10\%), are more exposed to successful stories about entrepreneurship when compared to the other groups. It seems that personally knowing an entrepreneur can really influence an individual to choose an entrepreneurial career, as shown by the Front-Runners. Unsurprisingly, despite the general positive influence towards entrepreneurship, only individuals from the Front-Runners quadrant, show higher levels of business opportunity recognition $(45.63 \%)$ in contrast to the Die-Hard group $(27.55 \%)$. In terms of "skills perception", almost $60 \%$ of the individuals from the GoGetter quadrant state that they have the proper knowledge, skills and experience to start a business. On the other hand, only $37.67 \%$ of the individuals from the Sugar-Coated group say that they are prepared to enterprise. The difference between these two groups highlights the role of education in entrepreneurship since those who are more educated 
tend to be less entrepreneurial. As expected, the Front-Runners reveal less fear of failure $(33.7 \%)$ as opposed to individuals from the Die-Hard quadrant $(44.67 \%)$. In regard to the dimension of "social regulation", it is clear that the majority of the individuals aim for equality and similar standards of living, which can symbolize the desire to flatten social gaps. As for "entrepreneurship desirability", more than $50 \%$ see entrepreneurship as a desirable career choice. Also, the recognition of a high level of "status" around this career choice $(63.62 \%)$ could positively influence the creation of such positive perception. This could be related to the understanding that starting a business is demanding $(65.96 \%)$ and, therefore, those who choose to pursue entrepreneurial pathways are recognized. In terms of "entrepreneurial exposure", in general, more than $50 \%$ of the individuals from all of the groups confirm that they are frequently exposed to successful business stories through media. Nevertheless, the Sugar-Coated group reveals the highest level of media exposure, which is surprising considering the lower rate of entrepreneurial initiative. As for the variable "Entrepreneurship easiness", individuals from the different quadrants, in general, believe that starting a business is not easy. Finally, regarding the variable "social-driven entrepreneurship", the majority recognizes that businesses are more focused on non-social problems. Despite this, the Go-Getter group reveals a higher propensity to tackle social dilemmas, reaching $36.09 \%$.

The variables used are moderately correlated, which proves the inexistence of multicollinearity (Table 4). The results of the Logistic Regression for all of the models are presented in Table 5.

Table 3. Descriptive Statistics.

\begin{tabular}{|c|c|c|c|c|c|c|c|c|c|c|c|}
\hline & & \multicolumn{2}{|c|}{ Die-Hard } & \multicolumn{2}{|c|}{ Go-Getter } & \multicolumn{2}{|c|}{ Sugar-Coated } & \multicolumn{2}{|c|}{ Front-Runners } & \multicolumn{2}{|c|}{ Entire Sample } \\
\hline & & $\mathbf{N}$ & $\%$ & $\mathbf{N}$ & $\%$ & $\mathbf{N}$ & $\%$ & $\mathbf{N}$ & $\%$ & $\mathbf{N}$ & $\%$ \\
\hline \multirow{2}{*}{ Entrepreneurial Initiative (EI) } & No & 38,740 & 94.45 & 9567 & 78.89 & 17,424 & 93.59 & 12,830 & 78.89 & 78,561 & 89.25 \\
\hline & Yes & 2278 & 5.55 & 2560 & 21.11 & 1194 & 6.41 & 3434 & 21.11 & 9466 & 10.75 \\
\hline \multirow{2}{*}{$\begin{array}{l}\text { Gender } \\
(\mathrm{GEN})\end{array}$} & Male & 20,438 & 49.66 & 5829 & 47.94 & 10,300 & 49.71 & 8040 & 49.29 & 44,607 & 49.38 \\
\hline & Female & 20,715 & 50.34 & 6329 & 52.06 & 10,419 & 50.29 & 8271 & 50.71 & 45,734 & 50.62 \\
\hline \multirow{6}{*}{$\begin{array}{l}\text { Age } \\
(\mathrm{AGE})\end{array}$} & G2 & 4532 & 11.01 & 2166 & 17.82 & 2195 & 10.59 & 2672 & 16.38 & 11,565 & 12.80 \\
\hline & G3 & 8145 & 19.79 & 2750 & 22.62 & 3537 & 17.07 & 3835 & 23.51 & 18,267 & 20.22 \\
\hline & G4 & 9525 & 23.15 & 2476 & 20.37 & 3497 & 16.88 & 3384 & 20.75 & 18,882 & 20.90 \\
\hline & G5 & 9005 & 21.88 & 2224 & 18.29 & 3881 & 18.73 & 2994 & 18.36 & 18,104 & 20.04 \\
\hline & G6 & 7511 & 18.25 & 1827 & 15.03 & 3360 & 16.21 & 2191 & 13.43 & 14,889 & 16.48 \\
\hline & G7 & 2435 & 5.92 & 715 & 5.88 & 2252 & 10.87 & 1235 & 7.57 & 6637 & 7.35 \\
\hline \multirow{7}{*}{$\begin{array}{l}\text { Education } \\
\text { (EDU) }\end{array}$} & L0 & 386 & 0.95 & 307 & 2.54 & 147 & 0.79 & 524 & 3.23 & 1364 & 1.56 \\
\hline & L1 & 6454 & 15.92 & 1504 & 12.45 & 792 & 4.28 & 1130 & 6.97 & 9880 & 11.31 \\
\hline & $\mathrm{L} 2$ & 7943 & 19.59 & 1689 & 13.98 & 1814 & 9.79 & 2870 & 17.71 & 14,316 & 16.39 \\
\hline & L3 & 10,232 & 25.24 & 5018 & 41.53 & 8063 & 43.53 & 5060 & 31.22 & 28,373 & 32.48 \\
\hline & $\mathrm{L} 4$ & 5409 & 13.34 & 1554 & 12.86 & 2667 & 14.40 & 2141 & 13.21 & 11,771 & 13.47 \\
\hline & L5 & 9671 & 23.85 & 1928 & 15.96 & 4863 & 26.25 & 3935 & 24.28 & 20,397 & 23.35 \\
\hline & L6 & 450 & 1.11 & 82 & 0.68 & 178 & 0.96 & 550 & 3.39 & 1260 & 1.44 \\
\hline \multirow{2}{*}{ Social context (SOC) } & No & 27,703 & 67.74 & 7482 & 61.97 & 12,638 & 69.05 & 9463 & 58.73 & 57,286 & 65.56 \\
\hline & Yes & 13,196 & 32.26 & 4591 & 38.03 & 5664 & 3.95 & 6649 & 41.27 & 30,100 & 34.44 \\
\hline \multirow{2}{*}{ Opp. Recognition (POR) } & No & 24,521 & 72.45 & 6503 & 58.61 & 7599 & 55.74 & 8022 & 54.37 & 48,014 & 63.61 \\
\hline & Yes & 9324 & 27.55 & 4593 & 41.39 & 6034 & 44.26 & 6732 & 45.63 & 27,176 & 36.39 \\
\hline \multirow{2}{*}{ Skills Perception (SKP) } & No & 22,279 & 55.77 & 4822 & 40.65 & 11,035 & 62.33 & 7576 & 47.80 & 45,712 & 53.55 \\
\hline & Yes & 17,668 & 44.23 & 7039 & 59.35 & 6669 & 37.67 & 8275 & 52.20 & 39,651 & 46.45 \\
\hline \multirow{2}{*}{ Fear to fail (FTF) } & No & 22,142 & 55.33 & 7476 & 63.10 & 10,301 & 58.19 & 10,591 & 66.30 & 50,510 & 59.05 \\
\hline & Yes & 17,875 & 44.67 & 4372 & 36.90 & 7401 & 41.81 & 5383 & 33.70 & 35,031 & 40.95 \\
\hline \multirow{2}{*}{ Social Regulation (SOR) } & No & 8658 & 30.37 & 3724 & 37.95 & 7380 & 42.01 & 5795 & 42.47 & 25,557 & 36.76 \\
\hline & Yes & 19,849 & 69.63 & 6088 & 62.05 & 10,186 & 57.99 & 7849 & 57.53 & 43,972 & 63.24 \\
\hline \multirow{2}{*}{ Entrepreneurship Desirability (END) } & No & 15,713 & 43,13 & 3556 & 36,80 & 8602 & 50.78 & 6059 & 39,23 & 33,930 & 43.23 \\
\hline & Yes & 20,719 & 56,87 & 6108 & 63,20 & 8338 & 49.22 & 9387 & 60,77 & 44,552 & 56.77 \\
\hline \multirow{2}{*}{ Entrepreneurship Status (ENS) } & No & 14,178 & 37.75 & 3828 & 39.96 & 5084 & 29.71 & 5894 & 38.25 & 28,984 & 36.38 \\
\hline & Yes & 23,380 & 62.25 & 5752 & 60.04 & 12,028 & 70.29 & 9516 & 61.75 & 50,676 & 63.62 \\
\hline \multirow{2}{*}{ Entrepreneurship Exposure (EEX) } & No & 17,603 & 46.34 & 3893 & 40.86 & 6535 & 38.90 & 6759 & 43.47 & 34,790 & 43.56 \\
\hline & Yes & 20,387 & 53.66 & 5635 & 59.14 & 10,264 & 61.10 & 8788 & 56.53 & 45,074 & 56.44 \\
\hline
\end{tabular}


Table 3. Cont.

\begin{tabular}{|c|c|c|c|c|c|c|c|c|c|c|c|}
\hline & & \multicolumn{2}{|c|}{ Die-Hard } & \multicolumn{2}{|c|}{ Go-Getter } & \multicolumn{2}{|c|}{ Sugar-Coated } & \multicolumn{2}{|c|}{ Front-Runners } & \multicolumn{2}{|c|}{ Entire Sample } \\
\hline & & $\mathbf{N}$ & $\%$ & $\mathbf{N}$ & $\%$ & $\mathbf{N}$ & $\%$ & $\mathbf{N}$ & $\%$ & $\mathbf{N}$ & $\%$ \\
\hline \multirow{2}{*}{ Entrepre. Easyness (EEA) } & No & 19,021 & 72.25 & 6435 & 66.60 & 5217 & 50.30 & 10,019 & 65.34 & 40,692 & 65.96 \\
\hline & Yes & 7305 & 27.75 & 3227 & 33.40 & 5154 & 49.70 & 5314 & 34.66 & 21,000 & 34.04 \\
\hline \multirow{2}{*}{ Entrep. Social-Driven (ESD) } & No & 19,425 & 71.84 & 6045 & 63.91 & 6944 & 67.63 & 9651 & 71.92 & 42,065 & 69.89 \\
\hline & Yes & 7616 & 28,16 & 3414 & 36.09 & 3324 & 32.37 & 3768 & 28.08 & 18,122 & 30.11 \\
\hline \multirow{2}{*}{ CAT } & G2 & 5141 & 12.49 & 12,158 & 100 & 2005 & 10.71 & 14,307 & 87.71 & 33,611 & 38.05 \\
\hline & G3 & 36,012 & 87.51 & 0 & 0.00 & 16,717 & 89.29 & 2004 & 12.29 & 54,733 & 61.95 \\
\hline
\end{tabular}

Table 4. Pearson Correlation Matrix.

\begin{tabular}{|c|c|c|c|c|c|c|c|c|c|c|c|c|c|c|c|}
\hline & 1 & 2 & 3 & 4 & 5 & 6 & 7 & 8 & 9 & 10 & 11 & 12 & 13 & 14 & 15 \\
\hline 1. EI & 1 & & & & & & & & & & & & & & \\
\hline 2. GEN & $-0.056 * *$ & 1 & & & & & & & & & & & & & \\
\hline 3. AGE & $-0.079 * *$ & $0.023^{* *}$ & 1 & & & & & & & & & & & & \\
\hline 4. EDU & $0.054 * *$ & -0.013 ** & -0.106 ** & 1 & & & & & & & & & & & \\
\hline 5. SOC & $0.174^{* *}$ & $-0.057^{* *}$ & $-0.110 * *$ & 0.106 ** & 1 & & & & & & & & & & \\
\hline 6. POR & $0.161^{* *}$ & $-0.052^{* *}$ & $-0.042 * *$ & $0.102^{* *}$ & $0.189 * *$ & 1 & & & & & & & & & \\
\hline 7. SKP & $0.238 * *$ & $-0.113 * *$ & $0.009^{*}$ & 0.128 ** & 0.230 ** & 0.155 ** & 1 & & & & & & & & \\
\hline 8. FTF & -0.101 ** & $0.071 * *$ & $-0.022 * *$ & $-0.029 * *$ & -0.046 ** & -0.101 ** & $-0.161^{* *}$ & 1 & & & & & & & \\
\hline 9. SOR & $-0.017^{* *}$ & $0.014^{* *}$ & $0.009 *$ & $-0.087^{* *}$ & -0.019 ** & 0.004 & -0.013 ** & $0.068^{* *}$ & 1 & & & & & & \\
\hline 10. END & 0.059 ** & 0.002 & -0.004 & $-0.078 * *$ & -0.003 & $0.111 * *$ & $0.038 * *$ & $-0.008^{*}$ & 0.138 ** & 1 & & & & & \\
\hline 11. ENS & $0.025^{* *}$ & -0.004 & $0.010^{* *}$ & 0.021 ** & -0.010 ** & $0.107^{* *}$ & -0.004 & $0.047^{* *}$ & $0.078^{* *}$ & $0.202 * *$ & 1 & & & & \\
\hline 12. EEX & $0.046^{* *}$ & -0.002 & $0.056 * *$ & -0.004 & 0.031 ** & $0.142 * *$ & $0.054 * *$ & -0.001 & $0.076 * *$ & $0.149 * *$ & $0.171^{* *}$ & 1 & & & \\
\hline 13. EEA & 0.055 ** & $-0.022 * *$ & 0.055 ** & $-0.022 * *$ & 0.060 ** & 0.220 ** & $0.079 * *$ & $-0.071^{* *}$ & $0.022 * *$ & 0.101 ** & 0.085 ** & 0.178 ** & & & \\
\hline 14. ESD & 0.040 ** & -0.003 & 0.043 ** & $-0.091 * *$ & $0.010^{*}$ & 0.108 ** & 0.047 ** & -0.004 & 0.107 ** & 0.163 ** & 0.125 ** & 0.215 ** & 0.203 ** & 1 & \\
\hline 15. CAT & $-0.208 * *$ & $-0.007 *$ & $0.113 * *$ & 0.075 ** & $-0.064^{* *}$ & -0.079 ** & $-0.082 * *$ & $0.082 * *$ & $0.085 * *$ & $-0.073^{* *}$ & $0.040 * *$ & -0.008 * & $0.009 *$ & $-0.048 * *$ & 1 \\
\hline
\end{tabular}

${ }^{*} p<0.05,{ }^{* *} p<0.01$ (two-tailed).

Table 5. Logistic Regressions.

\begin{tabular}{|c|c|c|c|c|c|}
\hline Variable & $\begin{array}{c}\text { Die-Hard } \\
\text { Model } 1\end{array}$ & $\begin{array}{l}\text { Go-Getter } \\
\text { Model } 2\end{array}$ & $\begin{array}{l}\text { Sugar-Coated } \\
\text { Model } 3\end{array}$ & $\begin{array}{l}\text { Front-Runners } \\
\text { Model } 4\end{array}$ & $\begin{array}{c}\text { All sample } \\
\text { Model } 5\end{array}$ \\
\hline GEN & $\begin{array}{c}-0.184^{* * *} \\
(0.066)\end{array}$ & $\begin{array}{c}-0.170 * * * \\
(0.059)\end{array}$ & $\begin{array}{c}-0.285^{* * *} \\
(0.102)\end{array}$ & $\begin{array}{c}-0.184^{* * *} \\
(0.049)\end{array}$ & $\begin{array}{c}-0.191^{* * *} \\
(0.031)\end{array}$ \\
\hline AGE & $\begin{array}{c}-0.052 * * * \\
(0.026)\end{array}$ & $\begin{array}{c}-0.125^{* * *} \\
(0.021)\end{array}$ & $\begin{array}{c}-0.162^{* * * *} \\
(0.035)\end{array}$ & $\begin{array}{c}-0.052^{* * *} \\
(0.017)\end{array}$ & $\begin{array}{c}-0.106^{* * *} \\
(0.011)\end{array}$ \\
\hline EDU & $\begin{array}{c}0.106^{* * *} \\
(0.025)\end{array}$ & $\begin{array}{l}-0.016 \\
(0.025)\end{array}$ & $\begin{array}{c}0.011 \\
(0.043)\end{array}$ & $\begin{array}{c}0.106^{* * *} \\
(0.018)\end{array}$ & $\begin{array}{c}0.065^{* * * *} \\
(0.012)\end{array}$ \\
\hline SOC & $\begin{array}{c}0.531^{* * *} \\
(0.068)\end{array}$ & $\begin{array}{c}0.512 * * * \\
(0.061)\end{array}$ & $\begin{array}{c}0.687^{* * *} \\
(0.103)\end{array}$ & $\begin{array}{c}0.531^{* * *} \\
(0.050)\end{array}$ & $\begin{array}{c}0.541^{* * *} \\
(0.032)\end{array}$ \\
\hline OPR & $\begin{array}{c}0.430 * * * \\
(0.070)\end{array}$ & $\begin{array}{c}0.521^{* * *} \\
(0.062)\end{array}$ & $\begin{array}{c}0.469^{* * *} \\
(0.106)\end{array}$ & $\begin{array}{c}0.430 * * * \\
(0.051)\end{array}$ & $\begin{array}{c}-0.486^{* * *} \\
(0.032)\end{array}$ \\
\hline SKP & $\begin{array}{c}1.400 * * * \\
(0.079)\end{array}$ & $\begin{array}{c}1.182 * * * \\
(0.076)\end{array}$ & $\begin{array}{c}1.344^{* * *} \\
(0.116)\end{array}$ & $\begin{array}{c}1.400 * * * \\
(0.060)\end{array}$ & $\begin{array}{c}1.299 * * * \\
(0.038)\end{array}$ \\
\hline FTF & $\begin{array}{c}-0.399 * * * \\
(0.071)\end{array}$ & $\begin{array}{c}-0.196^{* * *} \\
(0.066)\end{array}$ & $\begin{array}{c}-0.599^{* * * *} \\
(0.114)\end{array}$ & $\begin{array}{c}-0.399 \text { *** } \\
(0.057)\end{array}$ & $\begin{array}{c}-0.379 * * * \\
(0.035)\end{array}$ \\
\hline SOR & $\begin{array}{l}0.130^{*} \\
(0.069)\end{array}$ & $\begin{array}{c}0.031 \\
(0.062)\end{array}$ & $\begin{array}{l}-0.132 \\
(0.101)\end{array}$ & $\begin{array}{l}0.130^{* *} \\
(0.051)\end{array}$ & $\begin{array}{c}0.028 \\
(0.032)\end{array}$ \\
\hline END & $\begin{array}{l}0.151^{*} \\
(0.071)\end{array}$ & $\begin{array}{c}0.166^{* *} \\
(0.065)\end{array}$ & $\begin{array}{l}0.195^{*} \\
(0.101)\end{array}$ & $\begin{array}{c}0.151^{* * *} \\
(0.055)\end{array}$ & $\begin{array}{c}0.162^{* * *} \\
(0.034)\end{array}$ \\
\hline ENS & $\begin{array}{c}0.091 \\
(0.071)\end{array}$ & $\begin{array}{c}0.180 * * * \\
(0.064)\end{array}$ & $\begin{array}{l}-0.141 \\
(0.104)\end{array}$ & $\begin{array}{c}0.091 \\
(0.052)\end{array}$ & $\begin{array}{c}0.110 * * * \\
(0.033)\end{array}$ \\
\hline EEX & $\begin{array}{c}0.188^{* * * *} \\
(0.071)\end{array}$ & $\begin{array}{c}0.082 \\
(0.065)\end{array}$ & $\begin{array}{c}-0.251^{* *} \\
(0.102)\end{array}$ & $\begin{array}{c}0.188 \\
(0.052)\end{array}$ & $\begin{array}{c}0.133 * * * \\
(0.033)\end{array}$ \\
\hline EEA & $\begin{array}{l}-0.017 \\
(0.074)\end{array}$ & $\begin{array}{c}0.358^{* * *} \\
(0.064)\end{array}$ & $\begin{array}{c}-0.389^{* * * *} \\
(0.103)\end{array}$ & $\begin{array}{l}-0.017 \\
(0.053)\end{array}$ & $\begin{array}{c}0.043 \\
(0.033)\end{array}$ \\
\hline ESE & $\begin{array}{c}0.022 \\
(0.075)\end{array}$ & $\begin{array}{c}0.060 \\
(0.065)\end{array}$ & $\begin{array}{l}0.241^{* *} \\
(0.103)\end{array}$ & $\begin{array}{c}0.022 \\
(0.057)\end{array}$ & $\begin{array}{c}0.054 \\
(0.035)\end{array}$ \\
\hline Die-Hard & - & - & $\begin{array}{l}- \\
-\end{array}$ & - & - \\
\hline
\end{tabular}


Table 5. Cont.

\begin{tabular}{|c|c|c|c|c|c|}
\hline Variable & $\begin{array}{l}\text { Die-Hard } \\
\text { Model } 1\end{array}$ & $\begin{array}{l}\text { Go-Getter } \\
\text { Model } 2\end{array}$ & $\begin{array}{l}\text { Sugar-Coated } \\
\text { Model } 3\end{array}$ & $\begin{array}{l}\text { Front-Runners } \\
\text { Model } 4\end{array}$ & $\begin{array}{c}\text { All sample } \\
\text { Model } 5\end{array}$ \\
\hline \multirow[t]{2}{*}{ Go-Getter } & - & - & - & - & $0.723^{* * *}$ \\
\hline & - & - & - & - & $(0.059)$ \\
\hline \multirow[t]{2}{*}{ Sugar-Coated } & - & - & - & - & $0.139 * *$ \\
\hline & - & - & - & - & $(0.059)$ \\
\hline \multirow[t]{2}{*}{ Front-Runners } & - & - & - & - & $0.693^{* * *}$ \\
\hline & - & - & - & - & $(0.057)$ \\
\hline \multirow[t]{2}{*}{ CATGCR2 } & $-0.914^{* * *}$ & - & -0.175 & - & $-0.714^{* * *}$ \\
\hline & $(0.073)$ & - & $(0.117)$ & - & $(0.058)$ \\
\hline \multirow[t]{2}{*}{ Constant } & -2.890 & $-2.195 * * *$ & $-1.986^{* * *}$ & $-2.890 * * *$ & $-1.713^{* * *}$ \\
\hline & 0.251 & $(0.162)$ & $(0.329)$ & $(.0126)$ & $(0.171)$ \\
\hline
\end{tabular}

Note: $p<0.1^{*}, p<0.05^{* *}, p<0.01^{* * *}$ (SE): Standard Error.

With these results, it is evident that in each model Gender has a negative effect on the propensity to start a business and that it is significant in Model 1 ( $\beta=-0.184$; $p=0.007)$, Model $2(\beta=-0.170 ; p=0.004)$, Model $3(\beta=-0.285 ; p=0.005)$, and Model 4 $(\beta=-0.184 ; p=0.000)$. This reveals that women enterprise less when compared to their male counterparts. Age also has a negative effect on entrepreneurial initiative. This result holds for all of the models, which shows that older individuals tend to be less entrepreneurial. However, Education has a positive effect regarding Model 1 ( $\beta=-0.106$; $p=0.000)$ and Model $4(\beta=-0.106 ; p=0.000)$ and is strongly significant in both cases. Even though the studies indicate education as an enhancer for EI, it is surprising to see that it is only important in two groups. It is also clear that Social Context has a positive effect and is intensely significant in all of the models.

This suggests that knowing entrepreneurs personally and having a close interaction with them induces entrepreneurial careers more than education. This goes in line with studies that defend that role-modelling is an important influence on the diffusion of certain behaviors. Opportunity Recognition has a positive effect on EI regarding all of the models too. Such result shows that individuals that have more entrepreneurial alertness and that easily detect business opportunities tend to enterprise. Skills perception has a positive effect on choosing entrepreneurial journeys. The variable is strongly significant in all of the models. More than being educated, it is more important to have a positive perception of the skills, have knowledge and have some experience to enterprise. This reveals the importance of inner confidence.

Fear to fail has a negative effect on entrepreneurial initiative in all of the models. The results suggest that despite the diversity of the conditions, one can conclude that individuals' fear of failure is a deterring factor. For the individuals of the Die-Hard and Front-Runners group, Social Regulation affects EI positively. This could suggest that individuals are persuaded to follow entrepreneurship to reach a certain level, as a mean to flatten social gaps. Entrepreneurship desirability is positively significant in all of the models.

Entrepreneurship status has a positive effect in Model 2 and it becomes significant within the Go-Getter group ( $\beta=0.180 ; p=0.005$ ). Individuals from this group seek for recognition, which is a leverage to foster entrepreneurial initiative. Entrepreneurial Exposure has a positive effect in Models 1 and 3. Entrepreneurship Easiness has a negative effect in Model 3 ( $\beta=0.389 ; p=0.000)$ and reveals an opposite behavior in Model 2 $(\beta=0.358 ; p=0.000)$. Entrepreneurship Social-Driven has a positive effect in Model 3.

Model 5 exhibits a positive and significant effect on entrepreneurial initiative between taxonomic positions, evidencing that individual's enterprise more when moving to more advantage context. 


\subsection{Discussion and Policy Framework}

During the last decade, policy makers attempted to design effective entrepreneurship policies to incentive new business creation. Departing from successful cases, academics and practitioners grasped for miraculous recipes capable of being transported and adopted in different scenarios. In fact, entrepreneurship turned to be a hot topic with political appeal which instigated generalized support measures. In a contrary opinion, Shane [61] advocates that policy-makers must encourage the formation of high-growth companies and leave behind those with a low probability to growth. In this vein, policies must be designed to increase the rate of new business, attract the best entrepreneurs but, simultaneously, support high-growth businesses to ensure the raise of competitiveness, jobs and economic growth, without neglecting "aspiring" entrepreneurs.

The taxonomic perspective builds up from the level of entrepreneur to its context and feeds a multidimensional shift on the field. The entrepreneur is at heart of entrepreneurship process and the external conditions are crucial for building an ecosystem. Their interconnection can maximize the creation of a productive and sustainable entrepreneurship [27].

The entrepreneurial ecosystem taxonomy approach delivers a framework for the integration of insights from entrepreneurship research field and includes valuable novel contributions within an entrepreneurship policy framework (see Table 6). The recommendations are exposed according to the entrepreneurial ecosystem taxonomy, aiming to address each group singularities and to exploit its full potential.

The first group, Die-Hard, presents an adverse context conditions and a limited entrepreneurial initiative. The higher the performance in both dimensions, the more governments need to assess the existence of entrepreneurship bottlenecks and the areas that need to be developed more urgently [12]. While the improvement of EE could be a costly long-term investment, fostering individuals' desire to enterprise through economic incentives could lead to a positive growth and to strengthen entrepreneurial culture. As the group possesses the most vulnerable condition, fear of failure prevent them to act, government support is crucial to foster new venture initiation [61]. Simultaneously, the investment in education and training is also relevant since it reinforces individual's human capital, their exposure to successful entrepreneurial cases and the creation of entrepreneurial community [62,63]. The role of universities is, therefore, of paramount importance to promote a culture favoring entrepreneurship [64].

The second group represents countries with higher entrepreneurial initiative, despite the lack of entrepreneurial support conditions. The comparison between the first and second groups evidences a substantial difference regarding the effect of education. Although the literature points that educational patterns are important to innovative markets but also to traditional markets, particularly the importance of holding a university degree [65], this is not applicable within Go-Getter group. The raise of entrepreneurial initiative could turn entrepreneurship challenging in different spheres: Entrepreneurial breakout and masked entrepreneurial high-growth potential. Entrepreneurship is critical to economic growth, but it depends on the ability to retain and support valuable entrepreneurial ventures [66]. Potential high-growth entrepreneurs tend to evaluate the best location to develop the business, choosing to engage in vibrant EE. When EE do not offer the conditions to thrive - talent, support industries, or venture capital—entrepreneurs tend move to other contexts to access more adequate entrepreneurship support [67]. In another perspective, the government policies to support entrepreneurship could be flawed as the investment in entrepreneurship is wider [66], neglecting businesses that potentially lead to more innovation and economic growth. 
Table 6. Entrepreneurship Policy Framework recommendations.

Sugar-Coated

(Lateral Movement to Increase EI)
Front-Runners

(Maintain EEQ and EI)
- $\quad$ Build growth ambition with role-modelling, through the creation of tailored networks.

- $\quad$ Support the development of specific training programs to replace mainstream programs or accelerators, oriented to added-value projects.

- Support social-entrepreneurship with specific measures, tailored programs and specific funding schemes.
- $\quad$ Develop high value training, mentoring and coaching programs targeting managerial and strategic entrepreneurial challenges.

Long-term communication strategies focusing relevant entrepreneurship cases and growth companies.

Foster an environment driven by entrepreneurial impact, exposing entrepreneurs as game-changers.

- $\quad$ Reinforce the importance of sustainable entrepreneurship.

\section{Die-Hard \\ (Lateral and ascendant movement to increase EEQ and EI)}

\section{Go-Getter}

(Ascendant movement to increase EI)
- $\quad$ Provide an education system to support transversally individuals, leveraging opportunity recognition in more competitive fields.

- $\quad$ Recognize the importance of role-modelling and create more social engagement with entrepreneurs, instigated by networks of proximity.

- $\quad$ Support entrepreneurial career development, using formal (education) and informal (training, coaching and mentoring) approaches to reduce fear of failure and raise human capital.

- $\quad$ Raise entrepreneurial culture through communication and share entrepreneurship stories to stimulate entrepreneurship as a desirable career option, in multi-content platforms.

- Offer specific programs to support early-stage entrepreneurs.
- $\quad$ Offer entrepreneurship role-models and use social context to expand entrepreneurship desirability.

Strength the assessment of opportunities and offer support services to value-driven entrepreneurship. Tailored skills development programs using informal education strategies (training, coaching and mentoring) to more impactful business ideas.

- $\quad$ Emphasize entrepreneurship as a high-added value career option stimulating a culture of sustainable entrepreneurship and innovation-driven.

- $\quad$ Support specific funding schemes to leverage high potential projects using international networks. Build support services and infrastructures.

The third group, Sugar-Coated, is composed by countries with better EEs. Nevertheless, better conditions cannot be directly related with entrepreneurial initiative, as demonstrated by the empirical results. While the governments invested in developing EE in these countries, individuals are less attracted for an entrepreneurship career due to job market dynamics and favorable economic outlook. To stimulate entrepreneurial initiative in these contexts, institutions must act on specific programs with unique attributes, to attract entrepreneurs [67], namely, social oriented businesses. The motivation to promote social impact could act as a catalyst to overcome their fear of failure and increase their desire to enterprise. One of the government strategies could rely on accelerator programs devoted to support social entrepreneurs [68] to enhance their skills on the field and to expand interactions with diversified entrepreneurship agents. The alignment with the global sustainability agenda is relevant for tackling fundamental societal changes, induce individuals to embrace sustainable entrepreneurship [69] and enable the transition for a competitive position.

The last group, Front-Runners, represents the countries with superior performance in both dimensions; therefore, entrepreneurship policies should place a strong emphasis on the exploitation of EE potential to promote the transition to a sustainable entrepreneurial ecosystem [70] The cultural attributes of EEs must contribute significantly to sustainable businesses and simultaneously, act as a catalyst in developing economic and non-economic benefits at large [69].

The implementation of entrepreneurship policies encompasses the quality of ecosystems and the growth of entrepreneurial initiative, but the desirable pathway must be dependent on economies positioning and long-term goals, herein economic growth. 


\section{Conclusions and Policy Recommendations}

Few studies have analyzed the relationship between EEs and EI exploring both time and space perspective. As illustrated in the conceptual framework proposed for EE, coherent and holistic efforts to appraise EE can help identify which dimensions are more significant for each type of $\mathrm{EE}$, and it can also turn policies and strategies more adequate to the different ecosystems. Moreover, the taxonomic outlook around EE highlights the differences between the groups and, like a magnifier, it acknowledges the impact of different factors and their influence on entrepreneurial initiative.

This paper finds that all groups are positively ignited by a set of variables, such as Social Context, Opportunity Recognition, and Skills Perception. Additionally, it was found that Entrepreneurship Exposure has a positive effect in stimulating entrepreneurship in the countries that belong to the Die-hard group. Considering that these countries are placed below the average in terms of EEQ, the establishment of new public policies that make entrepreneurship more visible might lead to the creation of new enterprises. For the second group, Go-Getter, it is more important to have a positive perception of the easiness of starting a business. In that case, the establishment of public policies could be devoted to flattening the perception of entrepreneurship barriers since that could be a driver of entrepreneurial endeavors. Also, the group is positively influenced by status recognition. This suggests that measures that allow a wider recognition of entrepreneurs could induce others to pursue similar professional choices. As for the Sugar-Coated group, the results reveal the opposite since they are only positively affected by the need to solve social problems. Finally, the Front-Runners are induced by social regulation and the results suggest that individuals tend to grasp similar standards of living.

An important finding of the work is the understanding of education as an entrepreneurship driving force for the countries in the Die-Hard and the Front-Runners group only. Although several studies define education as an enhancer of entrepreneurial Initiative, the results demonstrate otherwise. Moreover, considering the levels of education of each group, it is possible to observe an interesting phenomenon: Education is important to the groups that have moderate education while it is irrelevant to those who are less educated or that have a higher level of education. The findings suggest that the more educated population does not pursue entrepreneurial pathways that often, which is most likely due to the fact that they have better job opportunities and a higher income. As for those less educated, the results suggest that people are necessity-driven regardless of the external conditions. In this setting, the individuals from the Go-Getter group tend to be more entrepreneurial oriented and to have different motivations. As for the remaining groupsDie-Hard, and Front-Runners-the taxonomy reveals the importance of EEs. In such cases, education allows individuals to perceive EE support conditions, stimulating entrepreneurs to use the available resources to usually ignite opportunity-driven businesses. In this way, entrepreneurs tend to become serial entrepreneurs to take advantage of the external conditions and support mechanisms.

The Entrepreneurial Ecosystem Taxonomy revealed that EEs are more influential on more educated groups, which highlights an elitist approach of the systems. Moreover, EE for those who pursue entrepreneurship as a survival condition is not so relevant.

Overall, this paper empirically extends the discussion around entrepreneurial ecosystems and its relationship with entrepreneurial initiative. Moreover, the new taxonomic approach brings attention to the differences between groups concerning Entrepreneurial Ecosystem Quality and allows us to appraise significant disparities around entrepreneurship determinants, which points outs the importance of developing specific policy packages for each group. This marks the need of having place-sensitive entrepreneurship policies, with tailored instruments for different countries. Despite entrepreneurship is currently embodied in the global economic development strategy, to spread entrepreneurial Initiative is not only a matter of rising ecosystem quality. The overarching model entails a structural understanding around entrepreneurship, but with divergent context-dependent instruments capable of exploit the available resources. 


\subsection{Theoretical Implications}

The proposed taxonomy focuses on entrepreneurial ecosystems and their quality in a global perspective. On one hand, the empirical study acknowledges the importance of external factors, herein entrepreneurial ecosystems, to instigate entrepreneurship and evidences the differences among territories. A broader perspective is offered placing countries in different positions according to their performance. On the other hand, by adopting a magnifying approach in each group, the study allows to recognize the variables and its differentiated impact within the four groups. Therefore, the relation between EEs and EI needs to be further developed, while the complexity of each EE system flourishes due to the transformation of forces [71]. While the empirical findings are encouraging, entrepreneurial ecosystems theory must be expanded.

First, the singularities detected confirm that entrepreneurial ecosystems are heterogeneous, therefore, "universalist" approaches need to be avoided [9]. Entrepreneurial ecosystems result from a combination of several factors, processes and agents with placed dynamics. The Entrepreneurial Ecosystem Taxonomy illustrates that EI determinants differ between groups, which contributed to capture the dynamic nature of entrepreneurial ecosystems [72] through its quality. More work is required to theoretically consolidate the EET approach and to expand the model with existing theories, as suggested by Wurth et al. [17]. Second, the comparison between EET profiles showed that entrepreneurship policies must avoid general conceptualizations and must rely on specific EI determinants, to ensure a transformative process of EE. The combination of short- and long-term measures to broaden entrepreneurship impact need to be fine-tuned emphasizing the importance of longitudinal research including other variables. The linkage with the evolutionary dynamics of EE proposed by Mack and Mayer [20] offers an additional research pathway to grasp a more detailed perspective of the cost-benefits of entrepreneurship policies. In essence, the theoretical framework contributes to addressing the "distance" between the entrepreneur and the entrepreneurship system. The results evidence a disconnection between entrepreneurship policies and real entrepreneurship challenges, suggesting the existence of "entrepreneurship myopia". The economic rationale behind the huge investment of governments and institutions on developing favorable EEs and entrepreneurial initiative is leading to an entrepreneurship imbalance. Third, the results point the development of self-sustaining and sustainable entrepreneurial ecosystems as urgent matters. A self-sustaining ecosystem must combine the development of the components to support entrepreneurship and the processes to refeed the system. While self-sustained EEs can be stronger vehicles to economic growth, sustainable EEs will permit to be driven by sustainable development goal. The combination of both trajectories, simultaneously, will lead to multiple benefits and to expand EE theorization.

\subsection{Practical Implications}

The framework EET represents a novel approach to the concept of EEs, opening the boundaries of theory but also providing practical utility, particularly, to entrepreneurship policymakers. The insights obtained based on empirical results conceive four different profiles-Die-hard, Go-Getter, Sugar-Coated, and Front-Runners-and permitted to extract the specific factors that hamper or foster EI. It is unquestionable that a positive change on $\mathrm{EE}$ and EI requires the implementation of articulated strategies, congruent to each group limitations and goals. Entrepreneurship policies need to address multi-level challenges and recognize the importance of coordinating the engagement of multiple agents [73].

The empirical results reveal that several EEs are trapped in an easily overshadow entrepreneurship agenda, with an EI that is out of proportion. Many EEs possess deficient conditions to stimulate new venture creation. However, individuals can be impelled to start a business, even within a less favorable context. For example, most economies are exploring strategies to address viable entrepreneurship and to remove barriers to its implementation, by placing entrepreneurs into the center of EEs [74]. Driven by factors such as the role-modelling and support to those who seize new opportunities, or are social- 
oriented, the practical agenda must acknowledge and target differently each context to enable entrepreneurship at large.

The empirical results also stress the relevance of self-sustaining EE as opposed to a subsistence model grounded on funding sources that provide limited support on EE development. The transformation of EEs on a self-sustaining system will probably slow short-term results, but the promotion of a culture of entrepreneurship is crucial to improve EI.

Encouraging entrepreneurship and addressing territories inequalities are a global concern, although countries feel the lack of resources and support measures differently. In sum, the integration of empirical findings on entrepreneurship public policy development can help to manage a more effective allocation of resources to promote entrepreneurship aligned with the singularities of each context.

\subsection{Limitations and Future Lines of Research}

The GEM database offers evidence about entrepreneurship phenomenon in a large number of countries, since 1999. GEM captures national dynamics around entrepreneurship and provides valuable insights for policymakers. Nevertheless, the participation on the study depends on each country, compromising the presence of all economies simultaneously, considering a longitudinal perspective. The sampled used encompassed 21 countries and was obtained after confirming the countries present along the 7 years. The present analysis covers only a portion of all economies, entailing the need to explore further to draw generalized conclusions. Prior years were not considered, since the suggested time span captures the length of more than one economic cycle to avoid short-term volatility.

Currently, the enlargement of the timespan is not possible, as the database is only available with 3 years of delay. As the data become accessible, the taxonomic perspective could be explored in a fine grain perspective along time and/or along space.

\subsection{Policy Recommendations}

The debate on entrepreneurial ecosystems cannot ignore a multidimensional approach where entrepreneurs act centrally. The ultimate effort on designing effective entrepreneurship policies aims to impact transversally the economies. However, narrowed strategies to support entrepreneurship can reduce the investments on entrepreneurship at large and impact more significantly entrepreneurial action in specific contexts. The empirical findings suggest a flexible bundle of policies to tackle entrepreneurship barriers.

Author Contributions: Conceptualization, M.P., J.C., and A.C.M.; methodology, M.P., J.C., and A.C.M.; validation, M.P., J.C., and A.C.M.; formal analysis, M.P., J.C., A.C.M.; investigation, M.P., J.C., and A.C.M.; resources, M.P., J.C., and A.C.M.; data curation, M.P., J.C., and A.C.M.; writing-original draft preparation, M.P.; writing-review and editing, M.P., J.C., and A.C.M.; visualization, M.P.; supervision, J.C. and A.C.M.; project administration, M.P., J.C., and A.C.M.; funding acquisition, M.P., J.C., and A.C.M. All authors have read and agreed to the published version of the manuscript.

Funding: This work was financially supported by the research unit on Governance, Competitiveness and Public Policy (UIDB/04058/2020) + (UIDP/04058/2020), funded by national funds through FCT-Fundacão para a Ciência e a Tecnologia.

Institutional Review Board Statement: Not applicable.

Informed Consent Statement: Not applicable.

Data Availability Statement: The datasets used for this study is publicly available at https://www. gemconsortium.org/data (access date 1 April 2020).

Conflicts of Interest: The authors declare no conflict of interest. 


\section{References}

1. Ali, A.; Espinosa, J.; Hart, M.; Kelley, D.; Levie, J. Leveraging Entrepreneurial Ambition and Innovation: A Global Perspective on Entrepreneurship, Competitiveness and Development. Available online: http://www3.weforum.org/docs/WEFUSA_ EntrepreneurialInnovation_Report.pdf\%5Cncontact@weforum.org (accessed on 19 November 2015).

2. Cao, Z.; Shi, X. A systematic literature review of entrepreneurial ecosystems in advanced and emerging economies. Small Bus. Econ. 2020. [CrossRef]

3. Mason, C.; Brown, R. Entrepreneurial Ecosystems and Growth-Oriented Entrepreneurship; OECD: Paris, France, 2014. [CrossRef]

4. European Commission. Entrepreneurship 2020 Action Plan: Reigniting the Entrepreneurial Spirit in Europe; European Commission: Brussels, Belgium, 2013.

5. Schmutzler, J.; Andonova, V.; Diaz-Serrano, L. How context shapes entrepreneurial self-efficacy as a driver of entrepreneurial intentions: A multilevel approach. Entrep. Theory Pract. 2019, 43, 880-920. [CrossRef]

6. Guerrero, M.; Liñán, F.; Cáceres-Carrasco, F. The influence of ecosystems on the entrepreneurship process: A comparison across developed and developing economies. Small Bus. Econ. 2020. [CrossRef]

7. Kansheba, M.; Wald, A. Entrepreneurial ecosystems: A systematic literature review and research agenda. J. Small Bus. Enterp. Dev. 2020, 27, 943-964. [CrossRef]

8. Acs, J.Z.; Stam, E.; Audretsch, D.B.; O'Connor, A. The lineages of the entrepreneurial ecosystem approach. Small Bus. Econ. 2017, 49,1-10. [CrossRef]

9. Roundy, P.T. "Small town" entrepreneurial ecosystems: Implications for developed and emerging economies. J. Entrep. Emerg. Econ. 2017, 9, 238-262. [CrossRef]

10. Groth, O.J.; Esposito, M.; Tse, T. What Europe needs is an innovation-driven entrepreneurship ecosystem: Introducing EDIE. Thunderbird Int. Bus. Rev. 2015, 57, 263-269. [CrossRef]

11. Xu, Z.; Dobson, S. Challenges of building entrepreneurial ecosystems in peripheral places. J. Entrep. Public Policy 2019, 8, 408-430. [CrossRef]

12. Content, J.; Bosma, N.; Jordaan, J.; Sanders, M. Entrepreneurial ecosystems, entrepreneurial activity and economic growth: New evidence from European regions. Reg. Stud. 2020, 54, 1007-1019. [CrossRef]

13. Kuratko, D.; Morris, M.; Schindehutte, M. Understanding the dynamics of entrepreneurship through framework approaches. Small Bus. Econ. 2015, 45, 1-13. [CrossRef]

14. Capelleras, J.L.; Contín-pilart, I.; Larraza-kintana, M.; Martin-sanchez, V. 'Regional Population Density and Entrepreneurial Growth Aspirations: The Moderating Role of Individual Human Capital', Druid15. 2015, pp. 3-25. Available online: http: //conference.druid.dk/acc_papers/dm4otqbobts3b5kjtm1cmafdble4.pdf (accessed on 5 January 2021).

15. Stam, E.; De Vem, A. Entrepreneurial ecosystem elements. Small Bus. Econ. 2019, 56, 809-832. [CrossRef]

16. Cavallo, A.; Ghezzi, A.; Balocco, R. Entrepreneurial ecosystem research: Opresent debates and future directions. Int. Entrep. Manag. J. 2019, 15, 1291-1321. [CrossRef]

17. Wurth, B.; Stam, E.; Spigel, B. Toward an entrepreneurial ecosystem research program. Entrep. Theory Pract. 2021, 1-50. [CrossRef]

18. Spigel, B. The Relational Organization of Entrepreneurial Ecosystems. Entrep. Theory Pract. 2017, 41, 49-72. [CrossRef]

19. Brown, R.; Mason, C. Looking inside the spiky bits: A critical review and conceptualisation of entrepreneurial ecosystems. Small Bus. Econ. 2017, 49, 11-30. [CrossRef]

20. Mack, E.; Mayer, H. The evolutionary dynamics of entrepreneurial ecosystems. Urban Stud. 2016, 53, 2118-2133. [CrossRef]

21. Dubina, N.; Campbell, D.; Carayannis, E.; Chub, A.; Grigoroudis, E.; Kozhevina, O.V. The Balanced Development of the Spatial Innovation and Entrepreneurial Ecosystem Based on Principles of the Systems Compromise: A Conceptual Framework. J. Knowl. Econ. 2017, 8, 438-455. [CrossRef]

22. Roundy, P.; Bayer, M. Entrepreneurial ecosystem narratives and the micro-foundations of regional entrepreneurship. Int. J. Entrep. Innov. 2019, 20, 194-208. [CrossRef]

23. Roundy, P.; Fayard, D. Dynamic Capabilities and Entrepreneurial Ecosystems: The Micro-Foundations of Regional Entrepreneurship. J. Entrep. 2019, 28, 94-120. [CrossRef]

24. Bosma, N. The Global Entrepreneurship Monitor (GEM) and its impact on entrepreneurship research. Found. Trends Entrep. 2013, 9, 143-248. [CrossRef]

25. Acs, Z;; Desai, S.; Hessels, J. Entrepreneurship, economic development and institutions. Small Bus. Econ. 2008, 31, 219-234. [CrossRef]

26. Malecki, E. Entrepreneurship and entrepreneurial ecosystems. Geogr. Compass 2018, 12, e12359. [CrossRef]

27. Stam, E. Entrepreneurial Ecosystems and Regional Policy: A Sympathetic Critique. Eur. Plan. Stud. 2015, 23, 1759-1769. [CrossRef]

28. Baumol, W. Joseph Schumpeter: The long run, and the short. J. Evol. Econ. 2013, 25, 37-43. [CrossRef]

29. Scott, S.; Venkataraman, S. The promise of entrepreneurship as a field of research. Acad. Manag. Rev. 2010, 25, 217-226.

30. Holcombe, R. The origins of entrepreneurial opportunities. Rev. Austrian Econ. 2003, 16, 25-43. [CrossRef]

31. Shrader, R.; Siegel, D. Relationship between Human Capital and Firm Performance. Entrep. Theory Pract. 2007, 312, 893-909. [CrossRef]

32. Fay, D.; Frese, M. The Concept of Personal Initiative: An Overview of Validity Studies. Hum. Perform. 2001, 14, 97-124. [CrossRef]

33. Nsereko, I.; Balunywa, W.; Munene, J.; Orobia, L.; Muhammed, N. Personal initiative: Its power in social entrepreneurial venture creation. Cogent Bus. Manag. 2018, 5, 1443686. [CrossRef]

34. Ajzen, I. The theory of planned behavior. Organ. Behav. Hum. Decis. Process. 1991, 50, 179-211. [CrossRef]

35. Krueger, N.; Reilly, M.; Carsrud, A. Competing models of entrepreneurial intentions. J. Bus. Ventur. 2000, 15, 411-432. [CrossRef] 
36. Díaz-Casero, J.; Hernández-Mogollón, R.; Roldán, J. A structural model of the antecedents to entrepreneurial capacity. Int. Small Bus. J. 2012, 30, 850-872. [CrossRef]

37. Levie, J.; Autio, E. A theoretical grounding and test of the GEM model. Small Bus. Econ. 2008, 31, 235-263. [CrossRef]

38. Sweetland, S. Human capital theory: Foundations of a field of inquiry. Rev. Educ. Res. 1996, 66, 341-359. [CrossRef]

39. Alvedalen, J.; Boschma, R. A critical review of entrepreneurial ecosystems research: Towards a future research agenda. Eur. Plan. Stud. 2017, 25, 887-903. [CrossRef]

40. Bischoff, K. A study on the perceived strength of sustainable entrepreneurial ecosystems on the dimensions of stakeholder theory and culture. Small Bus. Econ. 2021, 56, 1121-1140. [CrossRef]

41. Hakala, H.; O'Shea, G.; Farny, S.; Luoto, S. Re-storying the Business, Innovation and Entrepreneurial Ecosystem Concepts: The Model-Narrative Review Method. Int. J. Manag. Rev. 2020, 22, 10-32. [CrossRef]

42. Colombelli, A.; Paolucci, E.; Ughetto, E. Hierarchical and relational governance and the life cycle of entrepreneurial ecosystems. Small Bus. Econ. 2019, 52, 505-521. [CrossRef]

43. Brito, S.; Leitão, J. Mapping and defining entrepreneurial ecosystems: A systematic literature review. Knowl. Manag. Res. Pract. 2020, 19, 21-422. [CrossRef]

44. Isenberg, D. The Entrepreneurship Ecosystem Strategy as a New Paradigm for Economic Policy: Principles for Cultivating Entrepreneurships. Babson. 2011. Available online: http://www.wheda.com/uploadedFiles/Website/About_Wheda/ BabsonEntrepreneurshipEcosystemProject.pdf (accessed on 5 November 2020).

45. Spigel, B. Developing and governing entrepreneurial ecosystems: The structure of entrepreneurial support programs in Edinburgh, Scotland. Int. J. Innov. Reg. Dev. 2016, 7, 141. [CrossRef]

46. Audretsch, D.; Peña-Legazkue, I. Entrepreneurial activity and regional competitiveness: An introduction to the special issue. Small Bus. Econ. 2012, 39, 531-537. [CrossRef]

47. Neck, H.; Meyer, G.; Cohen, B.; Corbett, A. An Entrepreneurial System View of New Venture Creation. J. Small Bus. Manag. 2004, 42, 190-208. [CrossRef]

48. Porter, M. Competitive Advantage of Nations; Macmillan: New York, NY, USA, 1990.

49. Acs, Z.; Estrin, S.; Mickiewicz, T.; Szerb, L. Entrepreneurship, institutional economics, and economic growth: An ecosystem perspective. Small Bus. Econ. 2018, 51, 501-514. [CrossRef]

50. Acs, Z.; Amorós, J.; Bosma, N. From entrepreneurship to economic development: Celebrating ten years of global entrepreneurship monitor. Front. Entrep. Res. 2009, 29, 1. Available online: http:/ /digitalknowledge.babson.edu/fer/vol29/iss16/1/ (accessed on 5 April 2020).

51. Audretsch, D.; Cunningham, J.; Kuratko, D.; Lehmann, E.; Menter, M. Entrepreneurial ecosystems: Economic, technological, and societal impacts. J. Technol. Transf. 2019, 44, 313-325. [CrossRef] [PubMed]

52. Audretsch, D.; Keilbach, M. Entrepreneurship and regional growth: An evolutionary interpretation. J. Evol. Econ. 2004, 14, 605-616. [CrossRef]

53. Marič, M.; Znidarsic, J.; Dimovski, V.; Ferjan, M.; Djurica, M.; Jeraj, M.; Janezic, M. Country's Development as a Determinant of Early-Stage Entrepreneurial Activity. Organizacija 2013, 46, 75-86. [CrossRef]

54. Rodríguez-Pose, A.; Wilkie, C. Innovating in less developed regions: What drives patenting in the lagging regions of Europe and North America. Growth Chang. 2019, 50, 4-37. [CrossRef]

55. Rich, P. The Organizational Taxonomy: Definition and Design. Acad. Manag. Rev. 1992, 17, 758-781. [CrossRef]

56. Reynolds, P.; Bosma, N.; Autio, E.; Hunt, S.; De Bono, N.; Servais, I.; Lopez-Garcia, P.; Chin, N. Global entrepreneurship monitor: Data collection design and implementation 1998-2003. Small Bus. Econ. 2005, 24, 205-231. [CrossRef]

57. Levie, J.; Autio, E. Entrepreneurial Framework Conditions and National-Level Entrepreneurial Activity: Seven-Year Panel Study. In Proceedings of the Third Global Entrepreneurship Research Conference, Washington, DC, USA, 1-3 October 2007; pp. 1-39. Available online: http:/ / citeseerx.ist.psu.edu/viewdoc/download?doi=10.1.1.462.6312\&rep=rep1\&type=pdf; http: //www.gemconsortium.org/assets/uploads/1326045129Entrepreneurial_Framework_Conditions.pdf (accessed on 5 April 2020).

58. Hechavarria, D.; Ingram, A. Entrepreneurial ecosystem conditions and gendered national-level entrepreneurial activity: A 14-year panel study of GEM. Small Bus. Econ. 2019, 53, 431-458. [CrossRef]

59. Noguera, M.; Alvarez, C.; Urbano, D. Socio-cultural factors and female entrepreneurship. Int. Entrep. Manag. J. 2013, 9, 183-197. [CrossRef]

60. Pita, M.; Costa, J.; Moreira, A.C. Entrepreneurial Ecosystem Quality as an enhancer of Entrepreneurial Activity: A time and space review. In Proceedings of the International Conference on Regional Competitiveness, Tourism Innovation and Knowledge Transfer, Funchal, Portugal, 29 June-1 July 2020; pp. 37-38.

61. Shane, S. Why encouraging more people to become entrepreneurs is bad public policy. Small Bus. Econ. 2009, 33, 141-149. [CrossRef]

62. Mueller, S.; Thomas, A. Culture and entrepreneurial potential. J. Bus. Ventur. 2001, 16, 51-75. [CrossRef]

63. Van Trang, T.; Hung Do, Q.; Luong, M. Entrepreneurial human capital, role models, and fear of failure and start-up perception of feasibility among adults in Vietnam. Int. J. Eng. Bus. Manag. 2019, 11, 1-11. [CrossRef]

64. Ierapetritis, D. Discussing the role of universities in fostering regional entrepreneurial ecosystems. Economies 2019, 8, 119. [CrossRef]

65. Backes-Gellner, U.; Werner, A. Entrepreneurial signaling via education: A success factor in innovative start-ups. Small Bus. Econ. 2007, 29, 173-190. [CrossRef]

66. Lerner, J. The future of public efforts to boost entrepreneurship and venture capital. Small Bus. Econ. 2010, 35, 255-264. [CrossRef]

67. Brown, R.; Mawson, S.; Lee, N.; Peterson, L. Start-up factories, transnational entrepreneurs and entrepreneurial ecosystems: Unpacking the lure of start-up accelerator programs. Eur. Plan. Stud. 2019, 27, 885-904. [CrossRef] 
68. Pandey, S.; Lall, S.; Pandey, S.K.; Ahlawat, S. The appeal of social accelerators: What do social entrepreneurs value? J. Soc. Entrep. 2017, 8, 88-109. [CrossRef]

69. Volkmann, C.; Fichter, K.; Klofsten, M.; Audretsch, D. Sustainable entrepreneurial ecosystems: An emerging field of research. Small Bus. Econ. 2021, 56, 1047-1055. [CrossRef]

70. O'Shea, G.; Farny, S.; Hakala, H. The buzz before business: A design science study of a sustainable entrepreneurial ecosystem. Small Bus. Econ. 2021, 56, 1097-1120. [CrossRef]

71. Fredin, S.; Lidén, A. Entrepreneurial ecosystems: Towards a systemic approach to entrepreneurship? Geogr. Tidsskr. Dan. J. Geogr. 2020, 120, 87-97. [CrossRef]

72. Cantner, U.; Cunningham, J.; Lehmann, E.E.; Menter, M. Entrepreneurial ecosystems: A dynamic lifecycle model. Small Bus. Econ 2020, 1-18. [CrossRef]

73. Schot, J.; Steinmueller, W. Three frames for innovation policy: R\&D, systems of innovation and transformative change. Res. Policy 2018, 47, 1554-1567. [CrossRef]

74. Lux, A.; Macau, F.; Brown, K. Putting the entrepreneur back into entrepreneurial ecosystems. Int. J. Entrep. Behav. Res. 2020, 26, 1011-1041. [CrossRef] 